\title{
Coupling aerosol-cloud-radiative processes in the WRF-Chem model: Investigating the radiative impact of elevated point sources
}

\author{
E. G. Chapman, W. I. Gustafson Jr., R. C. Easter, J. C. Barnard, S. J. Ghan, M. S. Pekour, and J. D. Fast \\ Pacific Northwest National Laboratory, P.O. Box 999, Richland, 99352 Washington, USA
}

Received: 23 May 2008 - Published in Atmos. Chem. Phys. Discuss.: 1 August 2008

Revised: 6 January 2009 - Accepted: 6 January 2009 - Published: 6 February 2009

\begin{abstract}
The local and regional influence of elevated point sources on summertime aerosol forcing and cloud-aerosol interactions in northeastern North America was investigated using the WRF-Chem community model. The direct effects of aerosols on incoming solar radiation were simulated using existing modules to relate aerosol sizes and chemical composition to aerosol optical properties. Indirect effects were simulated by adding a prognostic treatment of cloud droplet number and adding modules that activate aerosol particles to form cloud droplets, simulate aqueous-phase chemistry, and tie a two-moment treatment of cloud water (cloud water mass and cloud droplet number) to precipitation and an existing radiation scheme. Fully interactive feedbacks thus were created within the modified model, with aerosols affecting cloud droplet number and cloud radiative properties, and clouds altering aerosol size and composition via aqueous processes, wet scavenging, and gas-phase-related photolytic processes. Comparisons of a baseline simulation with observations show that the model captured the general temporal cycle of aerosol optical depths (AODs) and produced clouds of comparable thickness to observations at approximately the proper times and places. The model overpredicted $\mathrm{SO}_{2}$ mixing ratios and $\mathrm{PM}_{2.5}$ mass, but reproduced the range of observed $\mathrm{SO}_{2}$ to sulfate aerosol ratios, suggesting that atmospheric oxidation processes leading to aerosol sulfate formation are captured in the model. The baseline simulation was compared to a sensitivity simulation in which all emissions at model levels above the surface layer were set to zero, thus removing stack emissions. Instantaneous, site-specific differences for aerosol and cloud related properties between the two simulations could be quite large, as removing abovesurface emission sources influenced when and where clouds formed within the modeling domain. When summed spa-
\end{abstract}

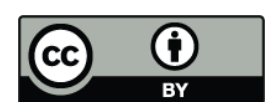

Correspondence to: E. G. Chapman (elaine.chapman@pnl.gov) tially over the finest resolution model domain (the extent of which corresponds to the typical size of a single global climate model grid cell) and temporally over a three day analysis period, total rainfall in the sensitivity simulation increased by $31 \%$ over that in the baseline simulation. Fewer optically thin clouds, arbitrarily defined as a cloud exhibiting an optical depth less than 1, formed in the sensitivity simulation. Domain-averaged AODs dropped from 0.46 in the baseline simulation to 0.38 in the sensitivity simulation. The overall net effect of additional aerosols attributable to primary particulates and aerosol precursors from point source emissions above the surface was a domain-averaged reduction of $5 \mathrm{~W} \mathrm{~m}^{-2}$ in mean daytime downwelling shortwave radiation.

\section{Introduction}

Current understanding of how aerosols affect weather and climate contains large uncertainties that must be reduced in order to better estimate the impact of anthropogenic emissions on the atmosphere. Incoming solar radiation can be scattered by aerosols, a "direct effect" associated with a cooling of both the surface and the atmosphere (Charlson et al., 1992; Kiehl and Briegleb, 1993). Incoming solar radiation also can be absorbed by aerosols consisting of black carbon and mineral dust, heating the local atmosphere and possibly reducing the incidence of cloud formation through the "semi-direct effect" (Hansen et al., 1997). Since particles also can act as cloud condensation nuclei (CCN) and/or ice nuclei (IN), aerosols may affect cloud microphysics, thus influencing overall cloud radiative properties through interactions referred to as the "first indirect effect" (Twomey, 1974; Twomey, 1991; Jones et al., 1994). Additionally, aerosols acting as CCN may affect precipitation efficiency, cloud lifetime, and cloud thickness, thus further affecting weather and climate through the "second indirect effect" (Albrecht, 1989; Pincus and Baker, 1994; Haywood and Boucher, 1999). With

Published by Copernicus Publications on behalf of the European Geosciences Union. 
aerosol lifetimes estimated at 1 to 2 weeks (Ramanathan et al., 2001) and distributions that generally are uneven horizontally and vertically, aerosol effects are anticipated to be highly variable and to occur both regionally and globally (Qian and Giorgi, 2000; Akimoto, 2003; Yu et al., 2006). As public debate involving climate change begins to focus on potential mitigation measures and regulatory actions, understanding and quantifying the influence of anthropogenic point sources, both primary particulate emitters and emitters of precursor trace gases, on atmospheric aerosol loading is of increasing interest.

Realistic simulation of the combined direct, semi-direct, and indirect effects of aerosols, irrespective of their source, requires models where the interactions of aerosols, meteorology, radiation, and chemistry are coupled in a fully interactive manner. The design of the community WRFChem model (Grell et al., 2005) permits such interactive coupling, and ultimately will allow investigations into feedbacks among various atmospheric processes. In contrast to global climate models (GCMs) with their coarse spatial resolution, feedback processes over a wide range of spatial scales can be investigated with WRF-Chem since it is a nonhydrostatic model that employs domain nesting (Skamarock et al., 2005). Fast et al. (2006) described the treatment of aerosol optical properties applied in WRF-Chem and evaluated simulated radiation and photolytic rates using data collected during the mostly clear-sky periods of the 2000 Texas Air Quality Study. Gustafson et al. (2007) used treatments of cloud-aerosol interactions and aerosol indirect effects implemented in WRF-Chem to investigate the impact of assumed $\mathrm{CCN}$ distributions on predicted cloud properties, finding that vertically- and temporally-varying $\mathrm{CCN}$ distributions were more likely to capture realistic regional cloud variations than the fixed CCN distributions typically employed by simpler GCMs.

Point source emissions are another factor affecting cloud evolution. Satellite images clearly show the local response of marine stratocumulus resulting from emissions from ships, known as "ship tracks." Ship track plumes contain large numbers of $\mathrm{CCN}$ that increase the number of cloud droplets while reducing droplet sizes (Hobbs et al., 2000), thereby increasing cloud albedo. Emissions from industrial and powerplant stacks likely have a similar effect, but their impact is more difficult to quantify since such point sources are often located in the vicinity of other large anthropogenic sources that contribute to background pollution and $\mathrm{CCN}$ levels. These sources influence downwind aerosol radiative forcing, and consequently climate. GCMs instantaneously mix point source emissions over a large grid cell, potentially neglecting important sub-grid scale non-linear chemistry (e.g., Gilliani and Pleim, 1996) and cloud-aerosol interactions (e.g., Ghan and Schwartz, 2007). The local and regional influence of point sources on cloud-aerosol interactions, including cloud optical properties and precipitation amounts, needs to be assessed, particularly since future climate-related emission control strategies designed for industrial and power-plant stacks may be easier to implement than for diffuse mobile and area sources.

In this paper, we use WRF-Chem to investigate the shortterm impact of elevated anthropogenic point sources on the net radiative forcing (direct, indirect, and semi-direct) over the northeastern US during a summer period. This region was selected because elevated industrial and power-plant stack emissions (Frost et al., 2006) contribute a large fraction of the overall precursors of particulates. We first describe the specific cloud-aerosol processes that form the basis of the model simulations, followed by a summary of our experimental method. Using observations collected during clear, partly-cloudy, and cloudy conditions, we then evaluate predicted meteorological, chemical, aerosol, and radiative quantities from a baseline simulation that contains all anthropogenic emission sources. Results from a sensitivity simulation that removes elevated stack emissions are then compared with the baseline simulation to assess their impact on surface radiation and cloud properties within a few hundred kilometers of the point sources. Finally, we discuss the implications of point source emissions on cloud-aerosol interactions in the model simulations.

\section{Model description}

The chemistry version of the Weather Research and Forecasting model (WRF-Chem) (Grell et al., 2005), version 2.1.2, as modified by Fast et al. (2006) formed the starting point for the model used in this study. The following is a brief summary of the primary WRF-Chem modules relevant to the current investigation; specific details are included in the cited references. All features discussed below are included in WRF-Chem version 3.0, publicly released in April 2008.

\subsection{Gas-phase chemistry}

Gas-phase atmospheric chemistry in this study is based on the CBM-Z mechanism (Zaveri and Peters, 1999) which uses 67 prognostic species and 164 reactions in a lumped structure approach that classifies organic compounds according to their internal bond types. Rates for photolytic reactions within $\mathrm{CBM}-\mathrm{Z}$ are derived using the Fast-J scheme (Wild et al., 2000; Barnard et al., 2004).

\subsection{Aerosol size distribution}

Aerosol size distributions were represented using a sectional approach. For this investigation, eight discrete size bins were selected with upper and lower bin diameters defined as shown in Table 1. Each bin is assumed to be internally mixed, i.e., all particles within a bin are assumed to have the same chemical composition. Both particle mass and particle number are simulated for each bin. Because bins are based on dry particle diameters, water uptake or loss will not 
Table 1. Sectional approach for aerosols: Particle dry-diameter ranges used in this study.

\begin{tabular}{lrrrrrrrr}
\hline & Bin 1 & Bin 2 & Bin 3 & Bin 4 & Bin 5 & Bin 6 & Bin 7 & Bin 8 \\
\hline Minimum Diameter $(\mu \mathrm{m})$ & 0.0390625 & 0.078125 & 0.15625 & 0.3125 & 0.625 & 1.25 & 2.5 & 5.0 \\
Maximum Diameter $(\mu \mathrm{m})$ & 0.078125 & 0.15625 & 0.3125 & 0.625 & 1.25 & 2.5 & 5.0 & 10.0
\end{tabular}

transfer particles between bins; however, particle growth or reduction due to chemical processes (e.g., chemical reaction, uptake/release of trace gases, etc.) and/or physical processes (e.g., coagulation, etc.) will produce such transfers. It should be noted that wet particle diameters (determined as a function of particle composition, relative humidity, temperature, and pressure) are also calculated and stored separately within the model.

Two aerosol nucleation schemes were added to WRFChem: a binary $\left(\mathrm{H}_{2} \mathrm{SO}_{4}-\mathrm{H}_{2} \mathrm{O}\right)$ nucleation scheme from Wexler et al. (1994) and a ternary $\left(\mathrm{H}_{2} \mathrm{SO}_{4}-\mathrm{NH}_{3}-\mathrm{H}_{2} \mathrm{O}\right) \mathrm{nu}-$ cleation scheme from Napari et al. (2002). The Napari et al. (2002) parameterizations include not only nucleation rates, but also parameterizations of particle number and particle radius of the critical nuclei. For this investigation, we employed Napari et al. (2002); however, Antilla et al. (2005) discuss problems with the original scheme that leads to nucleation rates that are higher than observed. Therefore, we plan to convert to their updated scheme as described by Merikanto et al. (2007) in the near future. There is recent evidence that organic compounds may play a role in new particle formation (e.g., Smith et al., 2008). However, organic nucleation mechanisms that can be incorporated into models are still in the early stages of development, and are not considered in this study.

Particle coagulation was incorporated into WRF-Chem via the method of Jacobson et al. (1994) using a Brownian kernel. This method is used by many atmospheric models and is applicable to any number of aerosol types and compositions.

\subsection{Aerosol chemistry}

An early version of the Model for Simulating Aerosol Interactions and Chemistry (MOSAIC) (Zaveri et al., 2008) and related thermodynamic and equilibrium modules (Zaveri et al., 2005a, b) were used in this work. MOSAIC treats major aerosol species including sulfate, methanesulfonate, nitrate, chloride, carbonate, ammonium, sodium, calcium, black carbon (BC), primary organic mass (OC) and liquid water. An additional component, "other inorganic mass" (OIN), is used to handle trace metals, silica and other inert minerals that might compose dust. Gas-phase species allowed to partition into the particle phase include sulfuric acid, nitric acid, hydrochloric acid, ammonia and methanesulfonic acid. Secondary organic aerosol formation was not treated in this investigation.
2.4 Aerosol-radiation interactions: Aerosol optics and direct effects

Aerosol chemical properties and sizes are used to determine aerosol optical properties as a function of wavelength using the method outlined in Fast et al. (2006). In brief, each chemical constituent of the aerosol is associated with a complex index of refraction. The overall refractive index for a given size bin is determined by volume averaging, with Mie theory and summation over all size bins used to determine composite aerosol optical properties. Wet particle diameters are used in the calculations. Once composite aerosol optical properties are known, the effect of aerosols on incoming solar radiation within WRF-Chem is determined by transferring relevant parameters to the Goddard shortwave radiation scheme (Chou et al., 1998).

\subsection{Aerosol-cloud-radiation interactions: Indirect effects}

The majority of additional capabilities added to WRF-Chem since Fast et al. (2006) and important to this investigation fall into this category. Foremost among them is a module to handle aerosol activation, the process by which aerosol particles form cloud droplets. Aerosol particles that do not activate to form cloud droplets remain in the interstitial air and are referred to as interstitial aerosols. Within the new module, activation of aerosols from the interstitial to the cloudborne "attachment state" (Ghan and Easter, 2006) is based on a maximum supersaturation determined from a Gaussian spectrum of updraft velocities and the internally mixed aerosol properties within each size bin (Abdul-Razzak and Ghan, 2002), similar to the methodology used in the MIRAGE general circulation model (Ghan et al., 1997, 2001 a, b, c; Zhang et al. 2002). For each aerosol size bin, both the number and mass fractions of aerosol particles activated each time step are determined, and thus both interstitial and cloud-borne aerosols are size-resolved. When cloud dissipates in a grid cell, cloud droplets evaporate and aerosols are resuspended, i.e., they transfer from the cloudborne to the interstitial state. As discussed in Section 2.2, chemical and physical processes may cause particles in either the activated or interstitial states to transfer into different aerosol size bins. Aerosol activation and resuspension are generally associated with vertical transport, and from a numerical standpoint it is desirable to calculate activation/resuspension and vertical transport simultaneously. The 
splitting of vertical advection and vertical turbulent mixing in WRF-Chem (and most other models) complicates this. In WRF-Chem the activation/resuspension are calculated simultaneously with turbulent vertical mixing, as in Ghan et al. (2001 a, b, c). With the grid resolutions employed in this study, most of the vertical transport in boundary-layer clouds is represented by vertical turbulent mixing. With the inclusion of the aerosol activiation/resuspension modules, WRFChem now has the capability to have the aerosol size distribution and composition directly contribute to the determination of $\mathrm{CCN}$.

A prognostic treatment of cloud droplet number (Ghan et al., 1997) was added to the Lin microphysics scheme (Lin et al., 1983; Rutledge and Hobbs, 1984; Tao et al., 1989; Chen and Sun, 2002), which treats water vapor and the following classes of hydrometeors: cloud water, rain, cloud ice, snow, and graupel. The parameterizations of Liu et al. (2005) were added to make the autoconversion of cloud droplets to rain droplets dependent on droplet number. Droplet-number nucleation and (complete) evaporation rates correspond to the aerosol activation and resuspension rates. A two-moment treatment of cloud water (cloud water mass and cloud droplet number) thus is now available within WRF-Chem.

Ice nuclei based on predicted particulates are not treated. However, ice clouds are included via the prescribed ice nuclei distribution that is an inherent part of the Lin scheme.

The interactions of clouds and incoming solar radiation are implemented in WRF-Chem by linking simulated cloud droplet number with the Goddard shortwave radiation scheme (first indirect effect) and the Lin et al. microphysics scheme (second indirect effect) (Skamarock et al., 2005). Thus, within the Goddard shortwave radiation scheme, droplet number will affect both the calculated droplet mean radius and cloud optical depth.

\subsection{Aqueous chemistry}

Cloud-borne aerosols and dissolved trace gases can interact via aqueous-phase processes. We have handled these processes by implementing the mechanism of Fahey and Pandis (2001) in a bulk approach. This mechanism includes 50 aqueous-phase species, 17 aqueous-phase ionic equilibria, 21 gas-phase/aqueous-phase reversible reactions, and 109 aqueous-phase chemical reactions. Oxidation of dissolved S(IV) by hydrogen peroxide, ozone, trace metals, and radical species are explicitly treated, as are the non-reactive uptake of nitric acid, hydrochloric acid, ammonia, and other trace gases. Aqueous chemistry processes can lead to the transfer of aerosol particles between size bins due to increased mass from cloud-borne sulfate, nitrate, ammonium, and other ions.

\subsection{Deposition}

Wet deposition of both trace gases and aerosols is now included in the model. In-cloud and below-cloud wet removal of aerosols and trace gases are treated. Within cloud, the cloud-borne aerosols and the fraction of trace gases dissolved in cloud water are collected by rain, graupel, and snow, using the corresponding first order loss rate of cloud water from the Lin microphysics scheme. Process modules involving belowcloud scavenging of aerosols by impaction/interception and selected trace gases by mass transfer have been implemented using the approach of Easter et al. (2004). All trace gas and aerosol species that are scavenged by precipitation are assumed to be immediately wet-deposited and removed from the model.

As before, dry deposition velocities of trace gases are calculated using a series resistance approach and the surface resistance parameterization of Wesely (1989). Dry deposition of aerosol particles, which affects both aerosol number and aerosol mass, is based on the approach of Binkowski and Shankar (1995).

\subsection{Advection scheme}

Chemical/aerosol species and moisture variables were advected using the positive definite advection scheme (Skamarock, 2006) released with WRF-Chem version 3.0. Simulations conducted early in our investigation, before this feature became available, produced substantially too much aerosol mass compared to observations. A large portion of the error was traced to numerical artifacts from the default advection routine in WRF; the default advection module produced negative mass values around the sharp gradients present near point source emissions, as well as in plumes occurring downwind of these point sources. Because negative mass represents a non-physical reality, the negative values were automatically replaced by zeros before calling the chemical modules, artificially adding mass to the model. A similar problem existed for cloud water mass, although to a lesser extent because clouds occur over regions larger than the point source emissions.

Figure 1 quantifies the error introduced by the default advection scheme when applied to point source emissions, using a simple test conducted by employing a doubly-periodic domain with emissions released from a single cell (at model level 3). In the test, WRF-Chem version 3.0 was configured in tracer mode with all physical and chemical processes turned off except for advection and emissions. A grid spacing of $2 \mathrm{~km}$ in an overall domain of $107 \times 103 \times 56$ points was employed, and the model initialized using a single meteorological profile, a sounding distributed with WRF. The ratio of the mass predicted to be within the model domain to the mass that should be in the domain is shown in Fig. 1. When using the default advection scheme, this ratio approached a value of 2 after $5 \mathrm{~h}$ of simulation, indicating that for the numerically worst case scenario of point emissions emanating from a single cell within the modeling domain, the model more than doubled the mass that should be present. Other tests (not shown) with larger grid spacings revealed that this doubling 


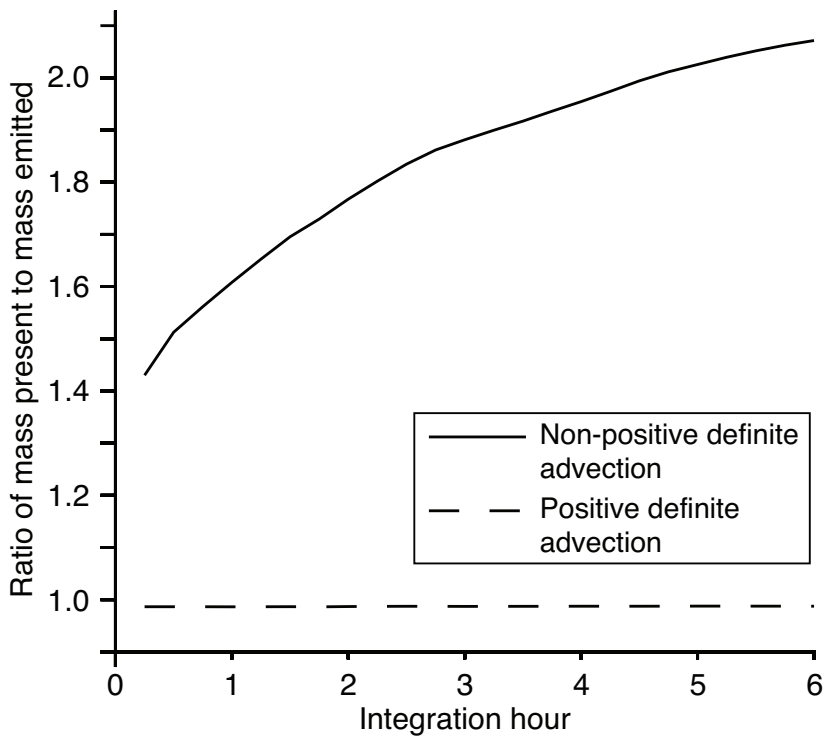

Fig. 1. Ratio of tracer mass present in the domain to mass emitted into the domain over a six-hour period for a single point source emitter. The solid line shows the ratio in a WRF-Chem run with the default non-positive definite advection scheme, while the dashed line shows the ratio when using the positive definite advection scheme.

was not highly sensitive to grid size. However, when the positive definite advection scheme was used, the ratio of predicted mass to emitted mass remained at 1 . Therefore, WRFChem users should not employ the default advection scheme.

When modeling cloud-aerosol interactions one also must be concerned with the possibility that non-linearities associated with the advection scheme may affect various aerosol and cloud species differently (Ovtchinnikov and Easter, 2008). This concern is not addressed in this work, but will need further attention in WRF-Chem to ensure accurate encapsulation of aerosol-cloud-climate interactions.

\subsection{Summary of process module changes}

The overall impact of adding new process modules and modifying existing modules as described above is that aerosol particles acting as $\mathrm{CCN}$ are now tightly coupled with the cloud physics portion of the WRF-Chem model. This coupling allows for fully interactive feedbacks; not only do aerosols affect cloud droplet number and cloud radiative properties, but clouds also alter aerosol size and composition via aqueous processes, wet scavenging, and gas-phase photolytic processes.

\section{Experimental method}

\subsection{Sources of observational data}

During the summer of 2004 several independent atmospheric field measurement programs were conducted in North America, each focusing on separate aspects of climate change and air quality issues. The International Consortium for Atmospheric Research on Transport and Transformation (ICARTT) was formed to coordinate and facilitate interaction among the various measurement programs (Fehsenfeld et al., 2006). The ICARTT/New England Air Quality Study (NEAQS) field campaign included some measurements of aerosol size distributions and composition, along with a suite of gas-phase chemistry, radiative, and meteorological measurements. Of particular interest for our modeling efforts were ICARTT/NEAQS 2004 measurements taken aloft by the US Department of Energy's (DOE's) Gulfstream-1 (G1) aircraft over a region encompassing central Pennsylvania, eastern Ohio, and southwestern New York, and measurements at a DOE ground "supersite" located at Indiana, Pennsylvania $\left(40.608^{\circ} \mathrm{N},-79.10^{\circ} \mathrm{W}\right)$. This geographic region includes numerous power plants with significant $\mathrm{SO}_{2}$ emissions, and meteorologically is prone to cloudy/partly cloudy skies. The combination should allow new aerosols, predominately in the form of sulfate particles, to form from both clear air and in-cloud processes, thus exercising the full suite of modules added to WRF-Chem. Additionally, a number of surface air quality stations regularly reporting hourly particulate mass measurements to the US Environmental Protection Agency's (EPA's) AIRNOW data base are located in the region, as are several National Weather Service stations. These features made data from the DOE portion of the ICARTT/NEAQS 2004 field campaign, supplemented with routine particulate and meteorological measurements, an attractive choice for initially evaluating the new modules added to WRF-Chem.

\subsection{WRF-Chem configuration}

For this investigation, WRF-Chem was configured with three nested domains using grid spacings of 18,6 , and $2 \mathrm{~km}$. The coarsest grid (Domain 1) covered the eastern United States and western North Atlantic, extending approximately from latitudes $30.89^{\circ} \mathrm{N}$ to $47.65^{\circ} \mathrm{N}$ and from longitudes $-6.60^{\circ} \mathrm{W}$ to $-91.40^{\circ} \mathrm{W}$, with 106 grid nodes in the eastwest direction and 102 in the north-south direction. As shown in Fig. 2, Domains 2 and 3 were centered over western Pennsylvania, near the location of the US DOE ICARTT/NEAQS 2004 supersite at Indiana, PA. Domain 2 extended 81 by 78 nodes while the finest grid, Domain 3, was 90 by 84 nodes. Domain 3 thus extended slightly less than $200 \mathrm{~km}$ square and was approximately the size of a typical, single GCM column. All domains extended 57 nodes in the vertical, from the surface to $100 \mathrm{hPa}$, with finer resolution near the surface. 

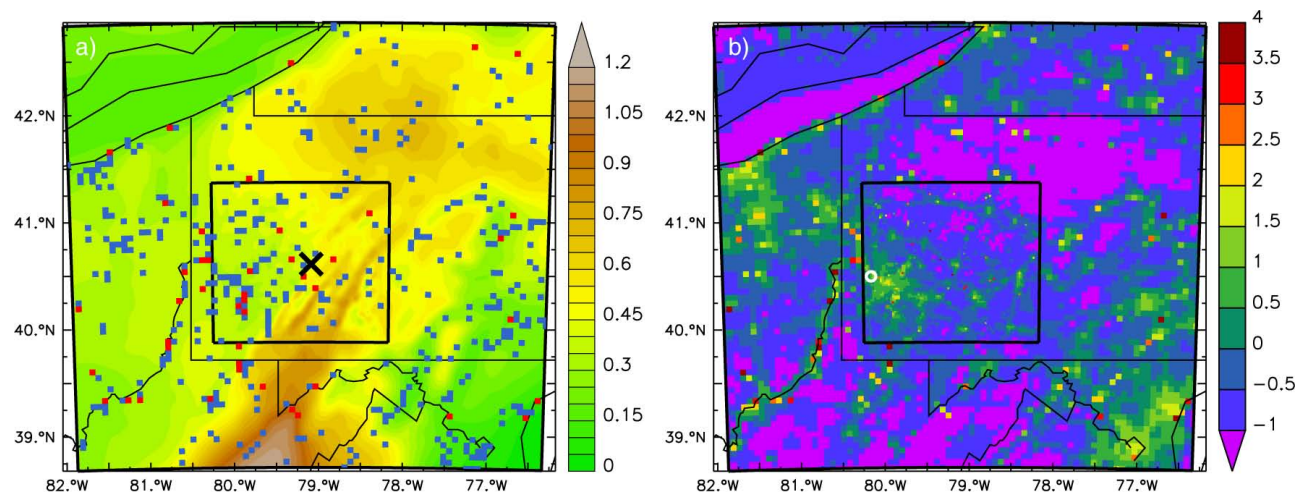

Fig. 2. (a) Topography of modeling Domain 2. The location of modeling Domain 3 is indicated by the inner black square while the black " $x$ " indicates the location of the Indiana, PA monitoring site. Blue squares represent point source stacks greater than $100 \mathrm{~m}$ in height while red squares indicate locations of major point source emitters where NEI99 emissions were replaced with US EPA CEMS data. Shading indicates the terrain height $(\mathrm{km})$. (b) $\mathrm{Log}$ of the $\mathrm{SO}_{2}$ emission flux averaged over the modeling analysis period in units of $\log \left(\mathrm{mol} \mathrm{km}^{-2} \mathrm{~h}^{-1}\right)$. The location of the National Weather Service KPIT site is denoted by the white circle.

Table 2. Selected WRF-Chem configuration options.

\begin{tabular}{ll}
\hline Atmospheric Process & WRF-Chem Option \\
\hline Longwave radiation & RRTM \\
Shortwave radiation & Goddard \\
Surface layer & Monin-Obukov \\
Land surface & Noah LSM \\
Boundary layer & YSU \\
Cumulus clouds & Kain-Fritsch, domain 1 only \\
Aerosol activation & Ghan, see text \\
Cloud microphysics & Enhanced Lin, see text \\
Gas-phase chemistry & CBM-Z \\
Aerosol chemistry & MOSAIC 8-bin \\
Aqueous-phase chemistry & Fahey and Pandis, see text \\
Photolysis & Fast-J \\
Advection & Skamarock positive definite, \\
& see text \\
\hline
\end{tabular}

The period 5 August 2004 12:00 UTC through $11 \mathrm{Au}-$ gust 2004 21:00 UTC was chosen for simulation. This period maximized the amount of observational data available from G-1 aircraft flights and ground supersite instrumentation, could be simulated in a reasonable amount of time on the available computing platform, and was after the period when Hurricane Alex likely would affect the model domains. In brief, overall synoptic meteorological conditions during the simulation period involved northerly winds until $8 \mathrm{Au}-$ gust, changing to westerly winds through 11 August. Two periods of heavy rain occurred, the first beginning late on 6 August and continuing into 7 August and the second beginning 10 August and continuing into the early hours of 11 August. Skies over the geographic area comprising Domains 2 and 3 were generally clear to partly cloudy on 9 August, changing to partly cloudy to cloudy on 10 August, with over- cast skies and areas of clearing beginning on 11 August. Simulation results prior to 9 August 06:00 UTC are classified as model spin up and are not treated in our analysis and discussion.

Table 2 summarizes the WRF-Chem configuration options selected for various atmospheric processes. Initial and lateral boundary conditions for meteorological variables were obtained from the North American Regional Reanalysis (NARR) (Mesinger et al., 2006). Initial ocean temperatures, soil temperatures, and soil moisture were also obtained from the NARR. Initial and lateral boundary conditions for trace gases and aerosols were derived from averaged August values for northeastern North America in MIRAGE GCM simulations (Easter et al., 2004).

Hourly aerosol and trace gas emissions were based on the US EPA's 1999 National Emissions Inventory (NEI99), version 3 (US EPA, 2003). NEI99 was the most recent version of the principal US air quality emissions inventory available at the time the model simulations were initiated. However, tall stack $\mathrm{NO}_{\mathrm{x}}$ and $\mathrm{SO}_{2}$ emissions for the August 2004 simulation period were expected to be significantly less than reported in NEI99 due to various emissions reduction programs established in response to the revised federal Clean Air Act Amendments. For example, the US EPA indicates that $\mathrm{NO}_{\mathrm{x}}$ emissions from power plants and other large combustion sources in the northeastern and mid-Atlantic states during May-September 2002 were reduced by approximately $60 \%$ relative to 1990 emissions, with substantial decreases in point source emissions from 1999 to 2000 and a continuing downward trend in early years of the 21 st century (US EPA, 2003). Work by Frost et al. (2005) conducted as part of ICARTT/NEAQS 2004 quantified substantial reductions in eastern $\mathrm{NO}_{\mathrm{x}}$ and $\mathrm{SO}_{2}$ power plant emissions and investigated the effect on regional ozone concentrations. Thus, to better reflect emission levels during the August 
2004 simulation period, NEI99 emission estimates for large point sources were replaced with actual hourly continuous emissions monitoring system (CEMS) $\mathrm{NO}_{\mathrm{x}}$ and $\mathrm{SO}_{2}$ data reported by the US EPA (http://www.epa.gov/airmarkets/ emissions/raw/index.html). Large point sources were arbitrarily defined as those stacks in Domains 2 and 3 emitting more than 24 tons $\mathrm{SO}_{2}$ day $^{-1}$. Additionally, all $\mathrm{NO}_{\mathrm{x}}$ and $\mathrm{SO}_{2}$ emissions from stacks greater than $100 \mathrm{~m}$ in height that were not replaced with CEMS data were adjusted by recommended factors of 0.51 and 0.87 (Frost et al., 2005), respectively, to reflect 1999-2004 point source emission trends. Locations of all adjusted point sources are shown in Fig. 2a. Figure $2 \mathrm{~b}$ shows mean column $\mathrm{SO}_{2}$ emissions (logarithmic scale) in Domains 2 and 3 when averaged over the entire modeling period. Note the high $\mathrm{SO}_{2}$ emissions in the Ohio River Valley and southwestern Pennsylvania, upwind of the supersite at Indiana, PA.

Primary particulate emissions in NEI99 include both particulate matter with diameters less or equal to than $2.5 \mu \mathrm{m}$ $\left(\mathrm{PM}_{2.5}\right)$ and particulate matter with diameters less than or equal to $10 \mu \mathrm{m}\left(\mathrm{PM}_{10}\right)$. Inventory $\mathrm{PM}_{2.5}$ emissions are speciated into categories of sulfate, nitrate, organic carbon, elemental carbon, and other unspecified matter, while $\mathrm{PM}_{10}$ emissions are simply reported as a total mass. The approach used to make inventory particulate emissions compatible with MOSAIC is consistent with that reported by Fast et al. (2006), i.e., other unspecified $\mathrm{PM}_{2.5}$ matter was assigned to the MOSAIC class of OIN and $\mathrm{PM}_{10}$ emissions were assigned a speciation profile equivalent to that of $\mathrm{PM}_{2.5}$.

\section{Model results: Comparison of baseline simulation with observations}

Local meteorological patterns strongly affect the transport and mixing of both trace gases and aerosols. We therefore begin the results section by briefly comparing predicted and observed meteorological quantities before presenting trace gas and aerosol results from the baseline simulation conducted using WRF-Chem configured as described in Sect. 3.2. Unless indicated otherwise, model results in this section are presented from Domain 3, the highest spatial resolution grid. When comparing model results with observations, it must be remembered that simulated values are representative of a $4 \mathrm{~km}^{2}$ area (for model Domain 3) while observations are point measurements.

\subsection{Meteorology}

Extensive meteorological evaluations of WRF and WRFChem have been the focus of previous studies (Jankov et al., 2005; McKeen et al., 2005, 2007). The comparisons presented here suggest that the WRF-Chem configuration employed for this study also adequately captured the overall evolution of local meteorology during the simulation period.
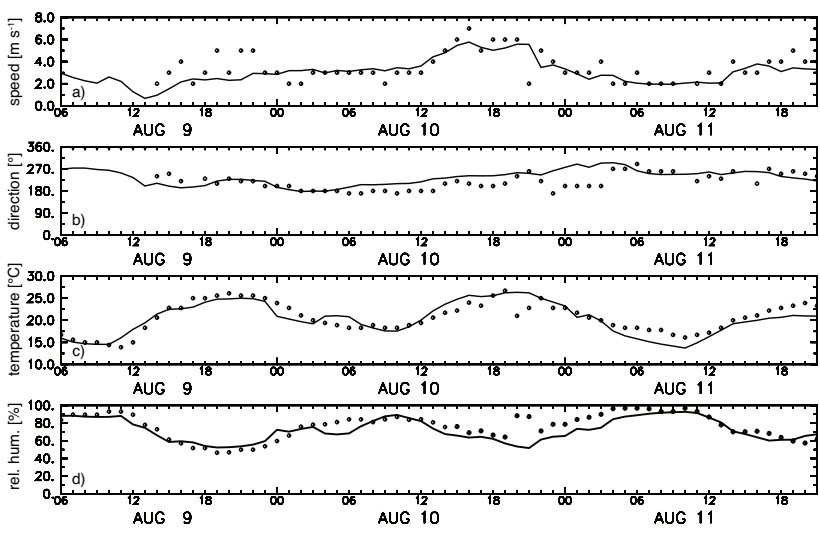

Fig. 3. Observed (circles) and simulated (line) wind speed, wind direction, temperature and relative humidity at the National Weather Service KPIT station between 06:00 UTC 9 August and 21:00 UTC 11 August 2004. Location of the KPIT station is shown in Fig. 2 b.

Wind speed, wind direction, temperature, and relative humidity observations were obtained from 10 National Weather Service (NWS) stations located in Domain 3. Figure 3 shows observed values at the Pittsburgh International Airport NWS site (NWS designation KPIT, located at $40^{\circ} 30^{\prime} 14^{\prime \prime} \mathrm{N} 80^{\circ} 15^{\prime}$ $59^{\prime \prime} \mathrm{W}$ ), which had a nearly complete data record and is representative of the 10 NWS stations. Simulation results for the WRF-Chem grid cell corresponding to the KPIT location are also shown. Note that the model captures the general trends of all four variables, although it slightly underpredicts wind speeds during local early morning and late afternoon of $9 \mathrm{Au}-$ gust, and underpredicts relative humidity during local early to mid- afternoon of 10 August. Some errors in wind direction also occurred, particularly on 10 August when simulated surface winds in this locale were more west-southwesterly while observed winds were more south-southwesterly. Comparisons with the less complete observational data sets at the remaining NWS stations were similar. Differences in modeled versus observed wind direction can lead to differences in pollutant plume locations, particularly if the errors are propagated vertically. Differences in modeled versus observed relative humidity may lead to differences in certain aerosol physical properties, as the amount of water associated with aerosols may vary, and, if occurring aloft, may affect the location and extent of clouds.

Pollutant transport is affected not only by surface winds but also by winds aloft. This is particularly true for pollutant emissions from large stacks. Figure 4 a shows observed wind speeds and directions as functions of height and time at the US DOE Indiana, PA supersite, as measured by a Vaisala Corporation $915 \mathrm{MHz}$ radar wind profiler, while Fig. 4b illustrates the corresponding values predicted by WRF-Chem. As shown there, the model captures general trends in local winds: lower winds speeds on 9 August, increased winds following a frontal passage on 10 August, and lower surface 


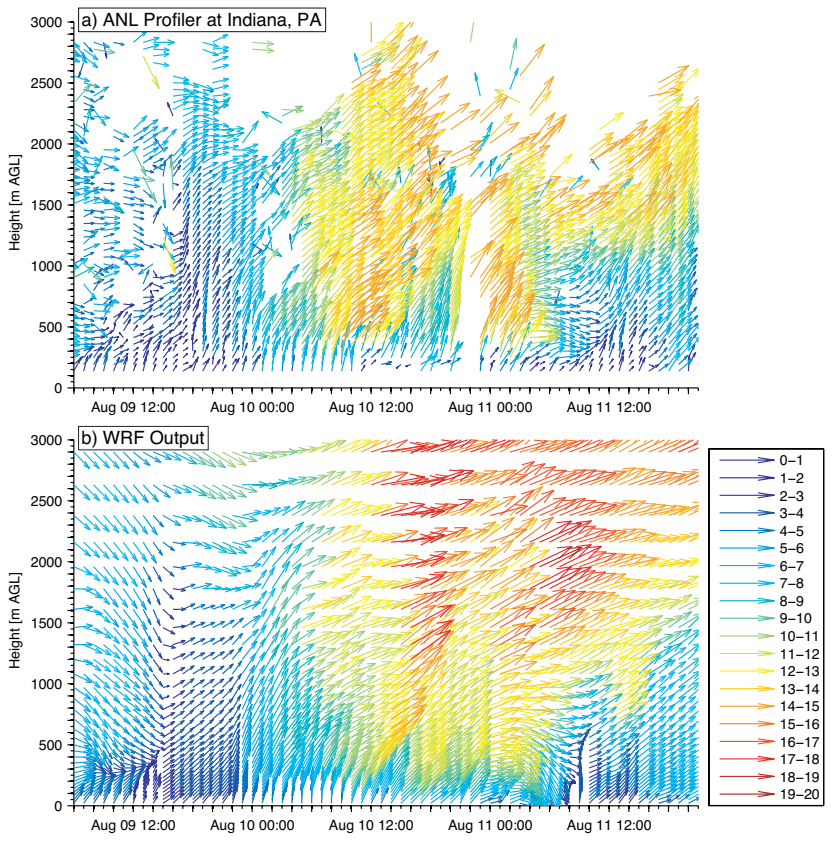

Fig. 4. Observed (top) and Domain 3 simulated (bottom) wind profiles at the Indiana, PA monitoring site.

winds but higher winds aloft on 11 August. Figure 4 also indicates that on 10 August, within the cell corresponding to the profiler site, the model predicts west-southwesterly winds both at the surface and aloft while observed winds are more south-southwesterly, similar to what was detected in the model-NWS surface station comparisons. At the profiler site, the model also tends to overpredict wind speeds above $1200 \mathrm{~m}$ on 10 August. However, the model does capture the decrease in wind speeds below $\sim 1100 \mathrm{~m}$ after about 09:00 UTC on this date, and the gradual shifts in both wind speed and direction that occur around 11 August 08:00 UTC. When coupled with surface comparisons, these results qualitatively suggest that overall the WRF-Chem configuration used in this study adequately captures major meteorological features occurring during the 9-11 August simulation period, but that some errors in predicted wind speed and direction occur. Such errors will offset simulated downwind plumes from their true locations and may affect comparisons of other trace gas and aerosol-related quantities. Use of 4-dimensional data assimilation (4DDA) in WRF-Chem (Liu et al. 2006), not publicly available when this study was initiated but released as part of WRF-Chem version 3.0, may help minimize meteorological errors and simplify physicochemical comparisons in the future.

\subsection{Trace gases and aerosols}

Trace gas and aerosol composition measurements from the US DOE's G-1 aircraft made on 9 August and 11 August are shown with simulated values in Figs. 5 and 6 respectively. Moving from west to east in the central part of the modeling domain, simulated $\mathrm{SO}_{2}$ values (Figs. 5a and 6a) clearly show the presence of plumes from the Cheswick (located at $\left.40.54^{\circ} \mathrm{N}-79.79^{\circ} \mathrm{W}\right)$, Keystone $\left(40.66^{\circ} \mathrm{N}-79.34^{\circ} \mathrm{W}\right)$, and Homer $\left(40.51^{\circ} \mathrm{N}-79.20^{\circ} \mathrm{W}\right)$ power plants, along with a plume from the Hatsfield Ferry power plant $\left(39.86^{\circ} \mathrm{N}\right.$ $-79.93^{\circ} \mathrm{W}$ ), located just off the southwestern edge of Domain 3. Simulated $\mathrm{SO}_{2}$ values are higher than observed on both days, and simulated plume locations are slightly to the south of plume locations inferred from observations. Deviations in plume locations are likely due to the propagation of small errors in predicted wind speed and direction, as discussed in Sect. 4.1. Deviations between predicted and observed mixing ratios may be due to over-estimates of $\mathrm{SO}_{2}$ in the emissions inventory, even with the use of CEMS-modified emissions, and to differences originating from actual versus simulated plume rise and associated mixing and dilution. Over-prediction of $\mathrm{SO}_{2}$ mixing ratios in ICARTT/NEAQS2004 modeling studies has been noted by others; Yu et al. (2007), for example, noted an average $\mathrm{SO}_{2}$ over-prediction of $77 \%$ relative to surface station observations when using NEI2001 with point source emissions modified to 2004 projections, and ascribed it to errors in the emissions inventories. Stern et al. (2008), in a regional model intercomparison study applied to Central Europe, also noted a tendency of some models to overpredict $\mathrm{SO}_{2}$.

The main source of continental atmospheric aerosol sulfate $\left(\mathrm{SO}_{4}\right)$ is the oxidation of gaseous $\mathrm{SO}_{2}$. If a model overpredicts $\mathrm{SO}_{2}$ mixing ratios, it will also overpredict atmospheric sulfate levels. However, if the atmospheric oxidation processes leading to aerosol sulfate formation are captured correctly in a model, then the observed and simulated ratios of $\mathrm{SO}_{2} / \mathrm{SO}_{4}$ should be similar, regardless of the absolute agreement of $\mathrm{SO}_{2}$ levels. As shown in Figs. $5 \mathrm{~b}$ and $6 \mathrm{~b}$, the model does well in capturing the observed range of ratios, although once again the location of the peaks shows slight deviations of observation-inferred and modeled plume locations. The ratio drops downwind from major power plant $\mathrm{SO}_{2}$ sources on both days. This behavior is expected, as time is required for both plume dilution and for oxidative processes to produce sufficient sulfate to affect the ratio. Although reaction rates are such that $\mathrm{SO}_{4}$ is produced faster when aqueous-phase pathways are available, both the model and G-1 observations indicate that clouds were not present in-plume on either day during the measurement period. Thus, $\mathrm{SO}_{2}$ oxidation by $\mathrm{OH}$ radical, the major sulfate-producing gas-phase reaction (Finlayson-Pitts and Pitts, 2000), was likely the major pathway available for sulfate production in this area at the time of both aircraft flights (approximately 17:30 UTC to 18:30 UTC on both 9 August and 11 August). 

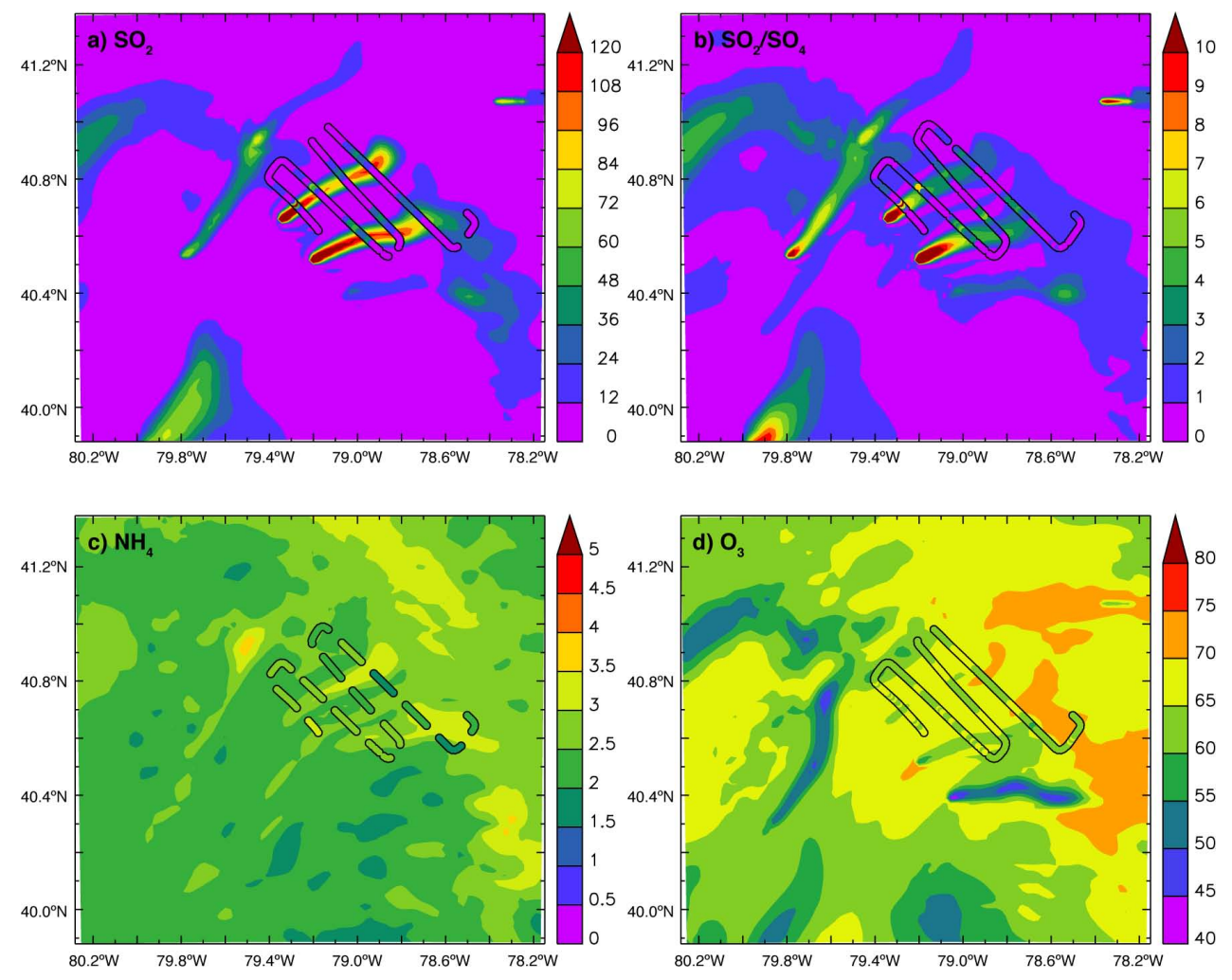

Fig. 5. Observed (tracks) and Domain 3 simulated (shading) values for (a) $\mathrm{SO}_{2}$, (b) $\mathrm{SO}_{2}$ to aerosol sulfate ratio (c) aerosol ammonium ion, and (d) ozone. Aircraft observations are from the G-1aircraft transect occurring 17:46 UTC to 18:30 UTC on 9 August at an altitude of 908 $\mathrm{m}$ above ground level (AGL). Simulated values are instantaneous model output at 18:00 UTC 9 August interpolated to the aircraft altitude. Units are parts-per-billion (ppb) for gaseous species and $\mu \mathrm{g} \mathrm{m}^{-3}$ for aerosol species.

Simulated ratios drop faster downwind of sources on sunny 9 August relative to overcast 11 August, consistent with faster photolysis rates and a higher overall oxidative capacity of the atmosphere on the clear day. Model results clearly indicate that the potential for aqueous-phase processing existed in other parts of the domain at the time of the G-1 flights, and indeed such a potential existed in at least a portion of the domain throughout the entire simulation period. Clouds generally occurred between 1 to $2 \mathrm{~km}$ above ground level (AGL) throughout Domain 3, deepening to approximately 1 to $4 \mathrm{~km}$ AGL during the 10 August frontal passage. Elevated mixing ratios of $\mathrm{SO}_{2}$ generally existed below $1.5 \mathrm{~km} \mathrm{AGL}$, rising to almost $2 \mathrm{~km}$ AGL on 10 August during the greater convective activity associated with the frontal passage.

Simulated and observed aerosol ammonium ion concentrations are shown in Figs. 5c and 6c. As seen there, predicted aerosol ammonium levels are slightly low on 9 August and slightly high on 11 August compared to observations, but generally are within $1.5 \mu \mathrm{g} \mathrm{m}^{-3}$ of observed values. When converted to a molar basis, both observed and simulated ammonium values are less than twice the aerosol $\mathrm{SO}_{4}$ values, suggesting that, in the area of the observations, there is insufficient ammonia present to neutralize all atmospheric aerosol sulfate.
Both observed and simulated ozone values are higher on the relatively sunny day of 9 August (Fig. 5d) compared to the overcast, post-rain period of 11 August (Fig. 6d). This is expected based on the known sensitivity of ozone production to photolytic processes. The model tends to slightly overpredict ozone mixing ratios. Note, for example, that on 9 August the model predicts ozone levels of 70-75 ppb in the east central part of the domain while measurements suggest ozone values in the range of 60-70 ppb. Similarly, on $11 \mathrm{Au}-$ gust the model predicts ozone mixing ratios of 55-65 ppb in the northeastern part of the domain while G-1 observations are in the range of 50-60 ppb. These slight errors may be due to over-estimates of $\mathrm{NO}_{\mathrm{x}}$ and VOC in the emissions inventories. Note that absolute ozone levels are not excessively high, reflecting moderately strong winds and ventilation during the simulation period. The simulated values are consistent with Frost et al.'s (2006) predicted Pennsylvania-area ozone levels in their ICARTT modeling study of the eastern US, conducted using a $27-\mathrm{km}$ grid resolution. High summertime ozone levels are usually associated with prolonged synoptic stagnation events where the combination of sunlight and the buildup of multiple days of emissions creates a photochemically rich reaction mixture. Meteorological conditions during the simulation period were not conducive to the 

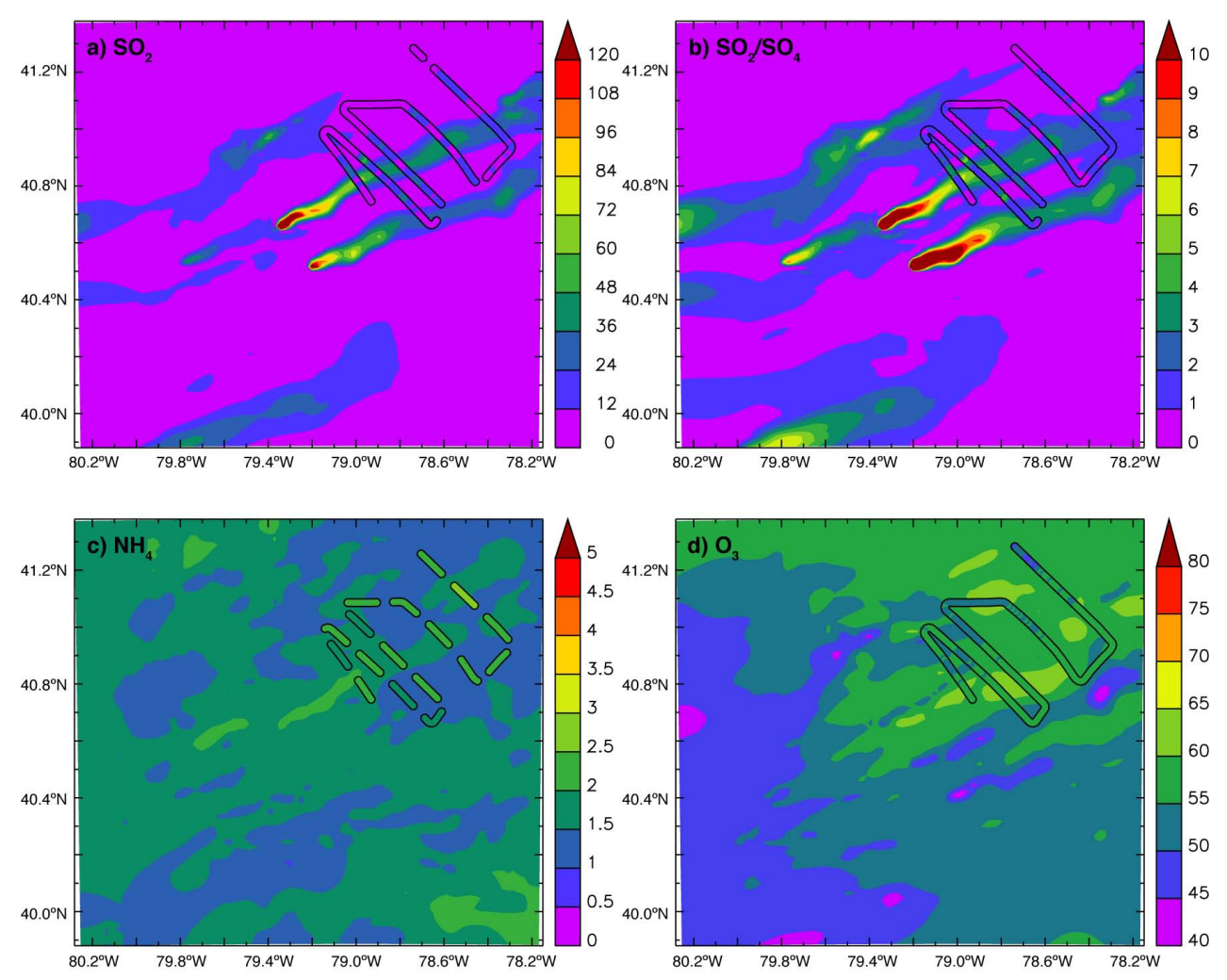

Fig. 6. Same as Fig. 5, but for the G-1 aircraft-transect occurring 17:38 UTC to 18:30 UTC on 11 August at an altitude of 937 m AGL. Simulated values are instantaneous model output at 18:00 UTC 11 August interpolated to the aircraft altitude.

formation of such stagnation events, and levels of both observed and simulated ozone mixing ratios are consistent with expected levels for this region of North America under such conditions.

To accurately represent activation of particles from an interstitial state into a cloud droplet, an atmospheric model must capture not only particle composition but also particle mass and the distribution of particle sizes. Observed and simulated particle size distributions are illustrated in Fig. 7. Observed particle number distributions were measured onboard the G-1 aircraft using the Brookhaven National Laboratory differential mobility analyzer (nominal size range 0.0169 $0.519 \mu \mathrm{m}$, segregated into 22 bins) and a PMS passive cavity axial scattering probe (PCASP), model 100X/DMT-SPP200 (nominal size range $0.1-3 \mu \mathrm{m}$, segregated into 30 bins). Via subsequent data analyses and instrument calibrations it was determined that only the first 16 channels of the PCASP instrument were producing usable data during the 9 August and 11 August flights. It is thus not possible to determine if the simulated fall-off in particle number for WRF-Chem aerosols greater than $0.625 \mu \mathrm{m}$ in diameter shown in Fig. 7 reflects what actually occurred in the atmosphere. However, such a fall-off is theoretically expected and normally observed (c.f., Finlayson-Pitts and Pitts, 2000 and Seinfeld and Pandis, 1998). Figure 7 suggests that on both days the number of particles associated with model Bin 1 is high rel- ative to observations. Recall from Sect. 2.2 that the original Napari et al. (2002) scheme has been shown to overestimate nucleation (Antilla et al., 2005) and likely led to predicted aerosol numbers in Bin 1 being higher than observed. Coagulation of small, freshly nucleated particles with larger, existing particles is unlikely to move the larger particles out of their current model bin, as the incremental size increase is small relative to bin spans (Table 1), and unlikely to drastically impact overall bin chemical composition. The influence of freshly nucleated particles on predicted direct and indirect radiative impacts is expected to be small; the largest contribution to aerosol optical depths is known to be from particles in the range of $0.2-1.0 \mu \mathrm{m}$ diameter, and, for the fairly polluted conditions (particle concentrations generally exceeding $5000 \mathrm{~cm}^{-3}$ ) and moderate updraft velocities in this study, the activation parameterization predicts that only particles with diameters larger than $\sim 0.1 \mathrm{~mm}$ are activated. Thus, particles in the accumulation mode size range will have the greatest influence on both direct and indirect forcing. In Fig. 7, the degree of similarity between observed and simulated number for the remaining bins on both sunny 9 August and overcast 11 August is encouraging, especially since the 11 August results suggest the model is doing an acceptable job of simulating the impacts of upwind cloud processes on at least the lower end of the WRF-Chem aerosol size distribution. 

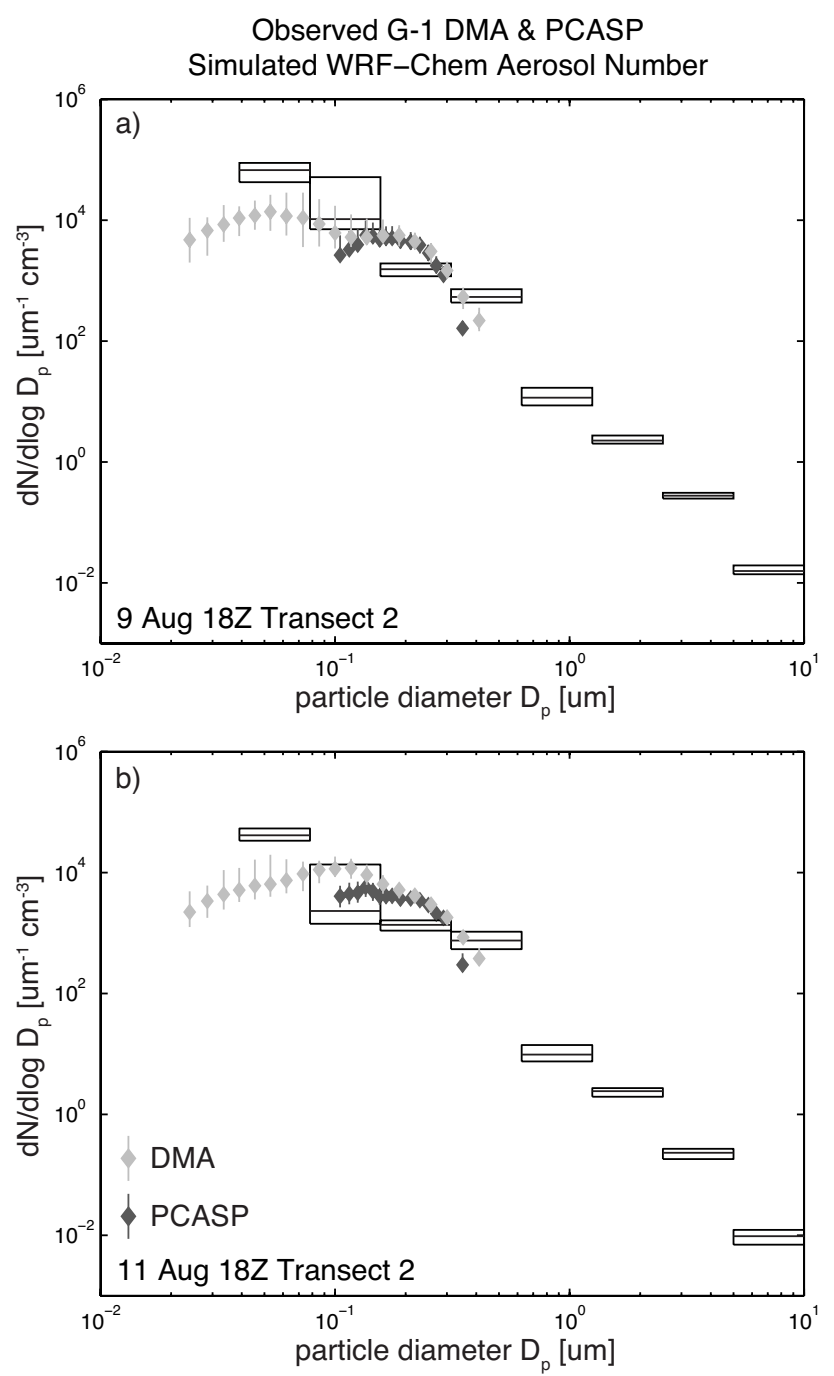

Fig. 7. Observed (symbols) and simulated (blocks) aerosol number for 9 August (top) and 11 August (bottom). Horizontal lines denote modeled median values for each size bin. Vertical lines denote observed range of $10 \%$ and $90 \%$ quantiles. Observations are from the G-1 aircraft transects corresponding to those shown in Figs. 5 and 6.

Predicted particle mass loadings in the form of $\mathrm{PM}_{2.5}$ concentrations were compared to observations submitted to the US EPA's Air Quality System (AQS). The AQS contains ambient air pollution data collected by varied state, local, and tribal agencies with equally varied monitoring objectives. Monitoring stations are classified as urban, suburban, rural, or unknown by the EPA. During the simulation period seven stations classified as suburban or rural and located within Domain 2 reported hourly $\mathrm{PM}_{2.5}$ mass concentrations. Figure 8a shows a scatter plot of hourly $\mathrm{PM}_{2.5}$ data from these seven stations versus $\mathrm{PM}_{2.5}$ mass concentrations predicted in the Domain 2 WRF-Chem grid cell corresponding to the station location. As seen there, predicted $\mathrm{PM}_{2.5}$ mass concentrations
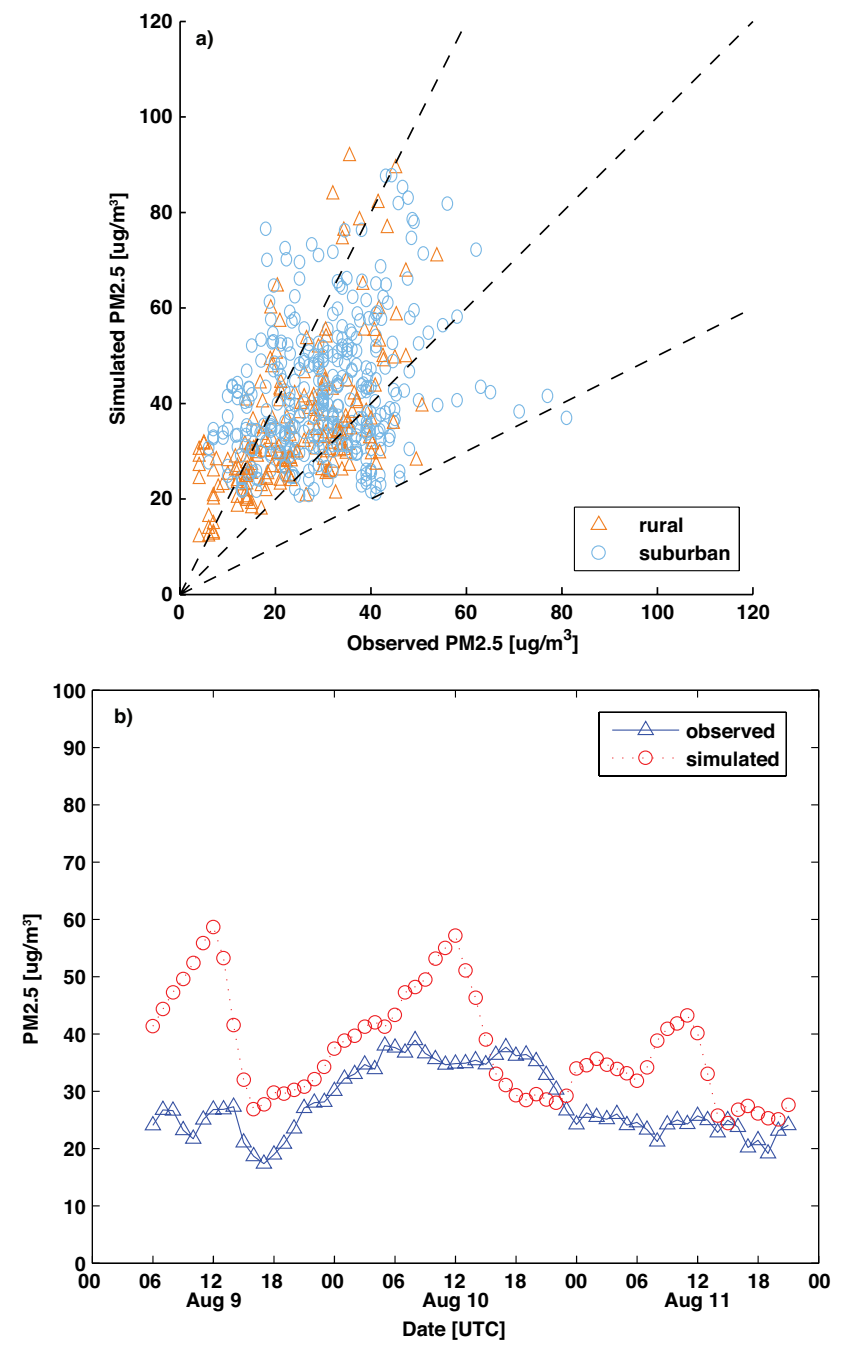

Fig. 8. (a) Observed and Domain 2 simulated $\mathrm{PM}_{2.5}$ at rural (orange) and suburban (light blue) monitoring stations reporting to the US EPA Air Quality System. Observations represent hourly averages while simulated values are instantaneous model output at the corresponding hour. Dashed lines indicate 2:1, 1:1, and 1:2 ratios. (b) temporal variation of observed (dark blue) and simulated (red) $\mathrm{PM}_{2.5}$ concentrations averaged over all monitoring sites.

generally are within a factor of two of observations, but with model predictions usually higher than observations. A recent European model intercomparison study also showed participating models generally to be within a factor of 2 of observations, but most models tended to underpredict both $\mathrm{PM}_{2.5}$ and $\mathrm{PM}_{10}$ mass (Stern et al. 2008). Figure $8 \mathrm{~b}$ shows the temporal response of the model; hourly $\mathrm{PM}_{2.5}$ observations from the seven reporting stations are averaged along with corresponding model values to form the comparative time series. As seen there, the model captures the general temporal trends of 9-10 August, mimicking the observed drop in $\mathrm{PM}_{2.5}$ concentrations shortly after 9 August 12:00 UTC followed by a gradual increase, and even reflects some of 
the smaller increased/decreased concentration cycles of 11 August. The ability of the WRF-Chem model as configured for this investigation to somewhat reproduce the observed aerosol temporal cycle is at least as good as and in many cases better than results reported with some other models and parameterizations (c.f., McKeen et al., 2007). However, the model predicts higher peak $\mathrm{PM}_{2.5}$ concentrations than observed, demonstrating, as in Fig. 8a, a fairly consistent bias towards higher $\mathrm{PM}_{2.5}$ concentrations.

The previously noted over-prediction of $\mathrm{SO}_{2}$ levels, most likely from errors in emissions, and subsequent overprediction of aerosol $\mathrm{SO}_{4}$ undoubtedly contributes to the bias in $\mathrm{PM}_{2.5}$. Primary particulate emissions in the NEI inventories used for this simulation may also have been too high. Minor meteorological errors yielding simulated boundary layers that are slightly too shallow would compound the problem, by mixing the aerosol mass through too small a volume. It is also possible that the model aerosol lateral boundary conditions, derived as previously noted from GCM simulations and representing average August values for northeastern North America, were too large for this simulation period. This would create a background level of aerosols that, when added to primary particulate emissions and particulates formed from atmospheric trace gas processing, also contributes to the observed positive bias. Slight errors in the location and timing of precipitation events also could contribute to differences between predicted and observed $\mathrm{PM}_{2.5}$ levels, as could uncertainties in the parameterized dry deposition of aerosols and aerosol precursors.

Limited ground aerosol composition data were available for the simulated period. A Sunset Laboratory SemiContinuous Carbon Analyzer (Model 3F) operating at the Indiana, PA supersite indicated that elemental carbon levels were $1 \mu \mathrm{g} \mathrm{C} \mathrm{m}^{-3}$ or less during the period 9 August 06:00 UTC through 11 August 21:00 UTC for particles less than $2.5 \mu \mathrm{m}$ in diameter. Simulated Domain 3 results for the nine model grid cells surrounding the surface site also indicated low levels, with modeled black carbon concentrations ranging from 0.37 to $2.9 \mu \mathrm{g} \mathrm{C} \mathrm{m}^{-3}$ with an average of $0.91 \mu \mathrm{g} \mathrm{C} \mathrm{m}^{-3}$.

\subsection{Radiative effects}

A multi-filter rotating shadowband radiometer (MFRSR) (Harrison et al., 1994) was used at the Indiana, PA monitoring site to obtain spectral measurements of the direct normal, diffuse horizontal, and total horizontal solar irradiances at six different wavelengths $(415,500,615,673,870$ and $940 \mathrm{~nm})$. From these measurements aerosol optical depths (AODs) and cloud optical depths (CODs) were inferred using the methods of Michalsky et al. (2001), Barnard and Long (2004), and Barnard et al. (2008). AODs are available only for clear-sky times while CODs are available only for fully overcast times, while downwelling shortwave radiation (SWR) is captured continuously.
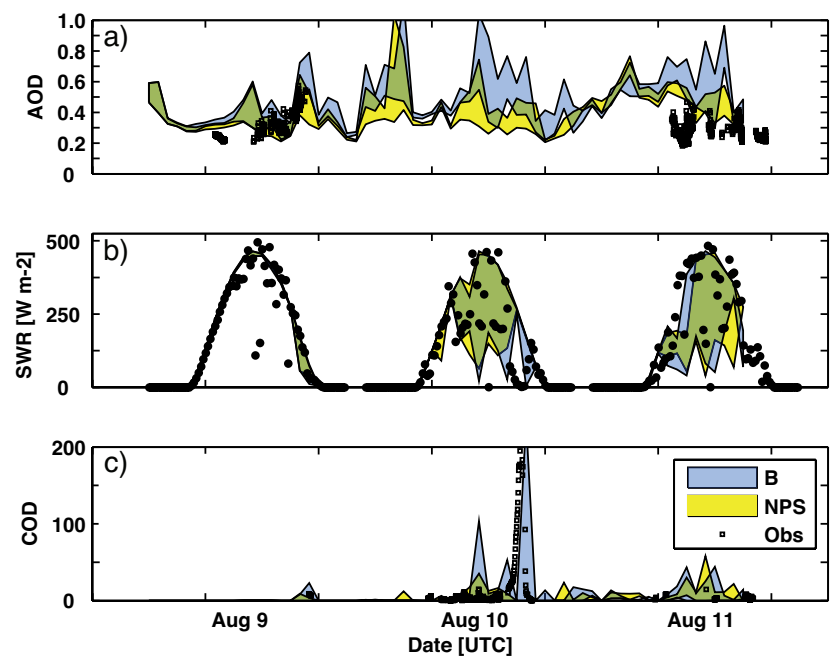

Fig. 9. Observed (squares) and Domain 3 simulated (shading) (a) aerosol optical depths, (b) shortwave downwelling radiation, and (c) cloud optical depths at Indiana, PA. Shading represents the range of values in the nine model surface cells surrounding the monitoring site. Baseline simulated values, with emissions, are shown in blue and no point source (NPS) simulated values in yellow; areas of overlap appear green. AOD observations are available only under clear sky conditions while COD observations are available only under fully overcast conditions.

Figure 9 plots quantities obtained from the MFRSR measurements along with the simulated values obtained for nine model grid cells centered on the Indiana, PA site. This range of values, representing an area within approximately $3 \mathrm{~km}$ of the monitoring site, is used rather than just the single value for the cell in which the monitoring site is located because of the potential for slight modeling errors in wind speed and direction noted previously. Such errors may cause the model to place aerosol plumes and clouds in the vicinity, but not necessarily at the exact observed location. All presented AODs represent values at a wavelength of $500 \mathrm{~nm}$.

As shown in Fig. 9, the model captures the general cycle of AODs from 9-11 August, although predicted AODs on 11 August (after the precipitation events of 10 August) are clearly too high. Generally too high a predicted AOD can be ascribed to either too much aerosol dry mass present in the model, too large a fraction of small particles for a given mass, or to an excess of water associated with the aerosols. As noted in Sect. 4.1, when simulated surface relative humidities deviate from observations at NWS stations (Fig. 3), the model tends to be slightly too dry rather than too moist. Additionally, the model captures quite well both the general diurnal cycle of observed SWR (Fig. 9b) and the onset of cloudy periods as indicated by reduced SWR levels and increased CODs (Fig. 9c) from MFRSR measurements. This is encouraging, as much of the simulation period near Indiana, PA experienced partly cloudy skies with shallow boundary layer clouds, a particularly difficult scenario for models 
Table 3. Domain emission totals for baseline (B) and no point source emission (NPS) simulations. Hourly emissions are summed for the period 9 August 06:00 UTC through 11 August 21:00 UTC. Units are metric tons.

\begin{tabular}{lrrrrrr}
\hline Domain & $\mathrm{SO}_{2}-\mathrm{B}$ & $\mathrm{SO}_{2}$-NPS & $\mathrm{NO}_{\mathrm{x}}-\mathrm{B}$ & $\mathrm{NO}_{\mathrm{x}}$-NPS & Particulates-B & Particulates-NPS \\
\hline 1 & 73760 & 7232 & 75612 & 52769 & 28930 & 23051 \\
2 & 16609 & 900 & 9525 & 6404 & 3432 & 2251 \\
3 & 3692 & 107 & 1621 & 1060 & 526 & 305 \\
\hline
\end{tabular}

to reproduce. Ranges of model values for the nine cells surrounding the Indiana, PA observation site indicate that the model is producing highly variable clouds, consistent with observations. Comparisons (not shown) throughout Domains 2 and 3 of cloud location, based on GOES-12 visible and infrared satellite images, also suggest the model was adequately capturing the timing and location of cloud formation.

Consideration of simulated vs. observed relative humidity, SWR, and CODs comparisons all suggest that the higher predicted AODs cannot be ascribed to an excess of aerosol water. However, given that precipitation events within the model remove aerosols and their precursors and thus affect post-event aerosol number and mass, too high an influx of post-event material from model emission sources or from model boundary inflow conditions could cause too rapid a buildup of aerosols within the modeling domains. The patterns observed in Fig. 9 are thus consistent with those in Fig. 8.

\subsection{Summary of baseline model evaluation}

Taken as a whole, the baseline model simulation is qualitatively similar to the available observations. The model appears to produce clouds of comparable optical thickness to observations at approximately the proper times. Simulated aerosol mass loadings tend to be higher than observed, although the aerosol size distributions appear consistent with the limited available data. Over-estimates of primary particulates and precursor gases, particularly $\mathrm{SO}_{2}$, in input emissions inventories may contribute to the higher simulated aerosol mass loadings, and higher-than-actual inflow aerosol boundary conditions may lead to a faster buildup of aerosols within the model after localized precipitation events. However, the model appears to be functioning well enough to investigate alternate scenarios, such as the potential radiative effects of point source emissions.

\section{Model results: comparison of baseline simulation with no point emissions simulation}

The radiative effects of point source emissions, both primary particulate emissions and precursor trace gases, were investigated by comparing the baseline simulation with a second simulation in which emissions at all model levels above the surface layer were set to zero. Because surface level emissions are mainly composed of vehicular and diffuse area sources, this action essentially eliminates point source emissions from the model run. This second simulation is thus referred to as the "no point source" (NPS) simulation. The NPS simulation was started at 9 August 06:00 UTC with all meteorological, trace gas, and aerosol quantities equal at that time to values predicted in the baseline simulation. This approach ensures that differences between the two simulations are due to differences in emissions within the modeling domains during the analysis period, and are not influenced by differences in model spin-up.

Table 3 lists domain emission totals for the entire simulation analysis period for both the baseline and NPS simulations. As expected, $\mathrm{SO}_{2}$ emissions were greatly reduced by eliminating point sources. $\mathrm{SO}_{2}$ emissions in the NPS simulation, for example, are less than $6 \%$ of those existing in the baseline simulation for Domain 2 and less than 3\% for Domain 3. Surface level emissions include vehicular emissions; thus $\mathrm{NO}_{\mathrm{x}}$ and particulate emissions are not reduced nearly as much as $\mathrm{SO}_{2}$. As shown in Table 3, total $\mathrm{NO}_{\mathrm{x}}$ and particulate emissions are each reduced by about one third in Domain 2 for the NPS simulation. In Domain 3, $\mathrm{NO}_{\mathrm{x}}$ emissions are also reduced by about one third, while primary particulate emissions drop by $42 \%$.

Figure 9 shows the impact of reduced emissions on the nine Domain 3 grid cells surrounding the Indiana, PA monitoring site. AODs from the NPS simulation are noticeably lower on both 10 and 11 August compared to the baseline simulation, except for a brief period around 08:00 UTC on the latter day that is associated with a substantial wind shift (Fig. 4). Even with point source emissions eliminated, simulated AODs do not drop below a value of approximately 0.2 due to contributions from surface particulate and precursor emissions, point source emissions prior to 9 August 06:00 UTC, and the inflow of aerosol from model lateral boundary conditions.

Recall that AOD is a measure of the degree to which aerosols reduce the transmission of solar radiation to the surface due to a combination of absorption and scattering. Aerosols composed of black carbon tend to absorb solar radiation while aerosols composed of sulfate tend to scatter solar radiation. The scattered sunlight becomes part of the diffuse beam, which, along with the direct beam, comprises 
Table 4. Comparison of predicted cloud properties in the baseline and no point source (NPS) simulations. Values are presented for Domain 3 mean cloud optical depth in cells containing cloud $\left(\mathrm{COD}_{\mathrm{COD}>0}\right)$; mean cloud optical depth in cells containing "non-thin" clouds $\left(\mathrm{COD} \mathrm{COD}_{>1}\right)$; number of model grid cells containing cloud $\left(\mathrm{N}_{\mathrm{COD}>0}\right)$; number of model grid cells containing "non-thin" clouds $\left(\mathrm{N}_{\mathrm{COD}>1}\right)$; total condensed water; total rainfall; mean aerosol optical depth (AOD); and mean daytime shortwave downwelling radiation (SWR). The number of model cells with "thin" clouds, arbitrarily defined as $0<\mathrm{COD} \leq 1$ and calculated as $\left(\mathrm{N}_{\mathrm{COD}>0}-\mathrm{N}_{\mathrm{COD}>1}\right)$, is also presented. Condensed water is defined as the integrated amount of condensed water in a model column reduced to the depth of the liquid if brought to the surface.

\begin{tabular}{|c|c|c|c|c|c|c|c|c|}
\hline & Baseline & NPS & Baseline & NPS & Baseline & NPS & Baseline & NPS \\
\hline & 9 Aug & 9 Aug & $10 \mathrm{Aug}$ & $10 \mathrm{Aug}$ & $11 \mathrm{Aug}$ & $11 \mathrm{Aug}$ & Overall & Overall \\
\hline Mean $\mathrm{COD}_{\mathrm{COD}>0}$ & 7 & 8 & 21 & 21 & 19 & 18 & 18 & 17 \\
\hline Mean $\mathrm{COD}_{\mathrm{COD}>1}$ & 13 & 14 & 37 & 36 & 24 & 22 & 26 & 25 \\
\hline $\mathrm{N}_{\mathrm{COD}>0}$ & 30250 & 30769 & 60571 & 59185 & 74616 & 74964 & 165437 & 164945 \\
\hline $\mathrm{N}_{\mathrm{COD}>1}$ & 15685 & 16392 & 33968 & 34464 & 61352 & 61815 & 111005 & 112671 \\
\hline $\mathrm{N}_{(0<\mathrm{COD} \leq 1)}$ & 14565 & 14377 & 26603 & 24721 & 13264 & 13149 & 54432 & 52274 \\
\hline Condensed Water $(\mathrm{cm})$ & 73 & 78 & 650 & 707 & 537 & 540 & 1260 & 1325 \\
\hline Rainfall (cm) & 0.01 & 0.01 & 429 & 595 & 54 & 38 & 483 & 633 \\
\hline Mean AOD & 0.42 & 0.36 & 0.49 & 0.39 & 0.45 & 0.39 & 0.46 & 0.38 \\
\hline $\operatorname{SWR}\left(\mathrm{W} \mathrm{m}^{-2}\right)$ & 521 & 522 & 403 & 408 & 342 & 350 & 423 & 428 \\
\hline
\end{tabular}

the SWR measurement. Thus, based on low levels of aerosol black carbon (both observed and simulated) and the fact that eliminating point sources had the biggest impact on $\mathrm{SO}_{2}$ emissions, it is not surprising that Fig. 9b shows only small differences in SWR levels between the baseline and NPS simulations. The "extra" aerosols in the baseline simulation scattered incoming solar radiation, but much of that scattered radiation still reaches the earth's surface at this location, consistent with expectations when aerosol asymmetry parameters generally are 0.5 and larger.

Figure 9c indicates that although clouds still form in the Indiana, PA area in the NPS simulation, they tend be optically thinner. Note, for example, that the very optically thick cloud observed circa 10 August 22:00 UTC is replicated in the baseline simulation but is not formed in the NPS simulation. When and where clouds form, and how optically thick they are, will also influence SWR levels.

This influence is shown in Table 4 where domain-wide differences in cloud properties and SWR are summarized for the two simulations. Mean quantities in this table are derived by averaging both spatially over Domain 3 and temporally over the indicated day or the overall analysis period (9 August 06:00 UTC through 11 August 21:00 UTC). Total quantities are derived by summing over the same spatial area and time span. Cells within five nodes of domain boundaries were excluded from the analysis to eliminate potential boundary effects. To better examine the impact of aerosols on cloud properties, "non-thin" clouds were arbitrarily defined to exist in cells exhibiting COD $>1$, and COD statistics were calculated both for cells where $\mathrm{COD}>0$ and for cells where COD $>1$. As shown in Table 4, the number of model cells exhibiting "thin" clouds (arbitrarily defined as $0<\mathrm{COD} \leq 1)$ is approximately $4 \%$ higher in baseline simula- tion than in NPS simulation. However, approximately $1.5 \%$ more "non-thin" clouds (COD $>1)$ formed in the NPS simulation. Considering both "thin" and "non-thin" clouds, the total number of cells exhibiting cloud (row $\mathrm{N}_{C O D>0}$ in Table 4) was slightly higher in baseline simulation, but day-today variations existed. Overall, clouds in the baseline simulation tended to be slightly more optically thick than the clouds in the NPS simulation. The amount of rainfall in the baseline simulation was less than in the NPS simulation, as was the total amount of condensed water. These results are consistent with expectations from the second indirect effect, namely that greater numbers of aerosols, such as in the baseline simulation, can lead to smaller cloud droplets and reduce the precipitation efficiency of clouds. Domain 3 mean AOD for the baseline simulation is $17 \%$ greater in than in the NPS simulation ( 0.46 vs. 0.38 ), consistent with having more aerosol mass present in the baseline simulation. The overall net effect of additional aerosols attributable to elevated point source emissions is a domain-averaged reduction of $5 \mathrm{~W} \mathrm{~m}^{-2}$ in mean daytime SWR, from $428 \mathrm{~W} \mathrm{~m}^{-2}$ in the NPS simulation to $423 \mathrm{~W} \mathrm{~m}^{-2}$ in the baseline simulation, a difference of just over $1 \%$.

Intuitively one expects that the impact of shutting off point source emissions should result in cleaner air masses gradually moving through the modeling domain. To test this expectation, Domain 2 AODs in both the baseline and NPS simulations were compared, segregated by distance and by date. Grid location $\mathrm{i}=41$ of Domain 2 (approximate longitude $79.1^{\circ} \mathrm{N}$ ) was somewhat arbitrarily chosen as the starting line for this comparison. This approach limits the comparison to that portion of the modeling domain east of major point sources in the Ohio River Valley and central Pennsylvania, and also permits inclusion of the Indiana, PA supersite. Cells 
Table 5. Aerosol optical depth summary statistics from baseline $\left(\mathrm{AOD}_{B}\right)$ and no point source $\left(\mathrm{AOD}_{\mathrm{NPS}}\right)$ simulations. Values are categorized temporally and spatially and include the number of cells $(\mathrm{N})$ in a given analysis; linear least square best fit slope (m), intercept (b) and correlation coefficient (r); root mean square (RMS) difference and normalized bias. Statistics are based on cells exhibiting COD $<1$ in both simulations. See text for explanation of cell range, which is used as a surrogate for downwind distance.

\begin{tabular}{|c|c|c|c|c|c|c|c|c|c|}
\hline Aug Day & Cell Range & Mean $\mathrm{AOD}_{B}$ & Mean AODNPS & $\mathrm{N}$ & $\mathrm{m}$ & $\mathrm{b}$ & $\mathrm{r}$ & RMS Difference & Normalized Bias \\
\hline 9 & $41-50$ & 0.32 & 0.31 & 7671 & 0.86 & 0.03 & 0.935 & 0.05 & -0.03 \\
\hline 9 & $51-60$ & 0.30 & 0.28 & 8437 & 0.71 & 0.07 & 0.880 & 0.08 & -0.02 \\
\hline 9 & $61-71$ & 0.27 & 0.26 & 10565 & 0.96 & 0.01 & 0.987 & 0.02 & -0.01 \\
\hline 10 & $41-50$ & 0.43 & 0.35 & 9213 & 0.57 & 0.10 & 0.713 & 0.15 & -0.15 \\
\hline 10 & $51-60$ & 0.46 & 0.36 & 8642 & 0.54 & 0.12 & 0.715 & 0.16 & -0.17 \\
\hline 10 & $61-71$ & 0.50 & 0.40 & 10072 & 0.48 & 0.16 & 0.649 & 0.21 & -0.16 \\
\hline 11 & $41-50$ & 0.34 & 0.30 & 5185 & 0.52 & 0.13 & 0.653 & 0.10 & -0.07 \\
\hline 11 & $51-60$ & 0.32 & 0.29 & 7809 & 0.43 & 0.15 & 0.606 & 0.09 & -0.07 \\
\hline 11 & $61-71$ & 0.33 & 0.29 & 8748 & 0.46 & 0.14 & 0.632 & 0.10 & -0.08 \\
\hline
\end{tabular}

within ten nodes of domain boundaries were excluded from this examination to eliminate potential edge effects from two-way nesting. Furthermore, the comparison was limited to clear or "thin cloud" cells, defined as grid cells exhibiting COD $<1$ in both the baseline and NPS simulations. Domain 2 rather than Domain 3 was used in this simulation-tosimulation comparative analysis because its larger size permits better examination of results as a function of distance.

Scatterplots of AODs computed in the baseline simulation $\left(\mathrm{AOD}_{B}\right)$ versus those computed in the NPS simulation $\left(\mathrm{AOD}_{\mathrm{NPS}}\right)$ are shown in Fig. 10 for 9, 10, and 11 August, and are color-coded as to distance from the arbitrary starting line. Results for cells in the range $41<=\mathrm{i}<=50$ are coded red and under strictly westerly flow would represent downwind distances of $0-60 \mathrm{~km}$ from the starting longitude. Similarly, cells $51<=\mathrm{i}<=60$, coded yellow, would represent $60-120 \mathrm{~km}$ distances while cells $61<=\mathrm{i}<=71$, coded blue, would represent $120-180 \mathrm{~km}$ distances. Linear least square best fit lines are also shown for each AOD grouping (similar color coding), along with the 1:1 line shown in black. Table 5 summarizes basic statistics for the daily AOD groupings, including linear least square best-fit slopes, intercepts and correlation coefficients between $\mathrm{AOD}_{B}$ and $\mathrm{AOD}_{\mathrm{NPS}}$. On 9 August cells most distant from the starting longitude show the least change between $\mathrm{AOD}_{B}$ and $\mathrm{AOD}_{\mathrm{NPS}}$, with a slope value close to 1 and the highest correlation coefficient $(\mathrm{r}=0.99)$ seen in this analysis. By 11 August, $\mathrm{AOD}_{B}$ and $\mathrm{AOD}_{\mathrm{NPS}}$ values for this distance grouping have diverged substantially; the slope has dropped to 0.46 and the correlation coefficient to 0.63 . This is consistent with expectations, since $\mathrm{SO}_{2}$ present at the 9 August 06:00 UTC NPS start time will continue to move across the modeling domain, gradually oxidizing to $\mathrm{SO}_{4}$ aerosol, just as it did in the baseline simulation, and leading to little differences in eastern simulated aerosols throughout 9 August. However, by 11 August these starting aerosols have exited the modeling domain, and the cleansing effects from localized precipitation events and the absence of point source emissions are noticeable. The lowest overall slope and correlation coefficient values ( 0.43 and 0.61 , respectively) are seen for the mid-distance cell grouping on 11 August, corresponding to the area just east of the region that received substantial precipitation on 10 August.

Instantaneous differences for aerosol and cloud related properties between the two simulations can be large. Domain 2 baseline simulation surface AODs and CODs at $10 \mathrm{Au}-$ gust 22:00 UTC are shown in Fig. 11a and b, respectively. Also shown in this figure are differences in these quantities between the baseline and NPS simulations, calculated as $\mathrm{AOD}_{B}-\mathrm{AOD}_{\mathrm{NPS}}$ (Fig. 11c) and $\mathrm{COD}_{B}-\mathrm{COD}_{\mathrm{NPS}}$ (Fig. 11d). As illustrated there, the elimination of elevated point source emissions leads to both higher and lower AODs and CODs across the domain. Removing elevated emission sources influenced when and where clouds formed. Examination of model results indicates differences among basic meteorological quantities between the baseline and NPS simulations that appear coupled to the cloud differences. For example, 10-m wind speeds differed by as much as $5 \mathrm{~m} \mathrm{~s}^{-1}$ at specific Domain 2 locations, with occasional variations of over $40^{\circ}$ in wind direction noted. Cumulative precipitation at specific locations differed by up to $3 \mathrm{~cm}$ while surface temperatures could vary by over $5 \mathrm{~K}$. Examination of exchange coefficients, used in implementing $\mathrm{K}$ theory within the model, suggests that at certain times and places substantial differences in the turbulent structure of the atmosphere exist between the two simulations.

This investigation suggests that, at least for the modeled time period, elimination of elevated point sources does have a radiative impact, with a temporally and spatially averaged increase of $5 \mathrm{~W} \mathrm{~m}^{-2}$ in SWR noted in the Domain 3 NPS simulation relative to the baseline simulation, with a number of other simulated variables (Table 4) also affected. Longer simulation periods, however, are needed to determine if the changes are typical and will persist, or if they will average out and disappear when different synoptic systems 

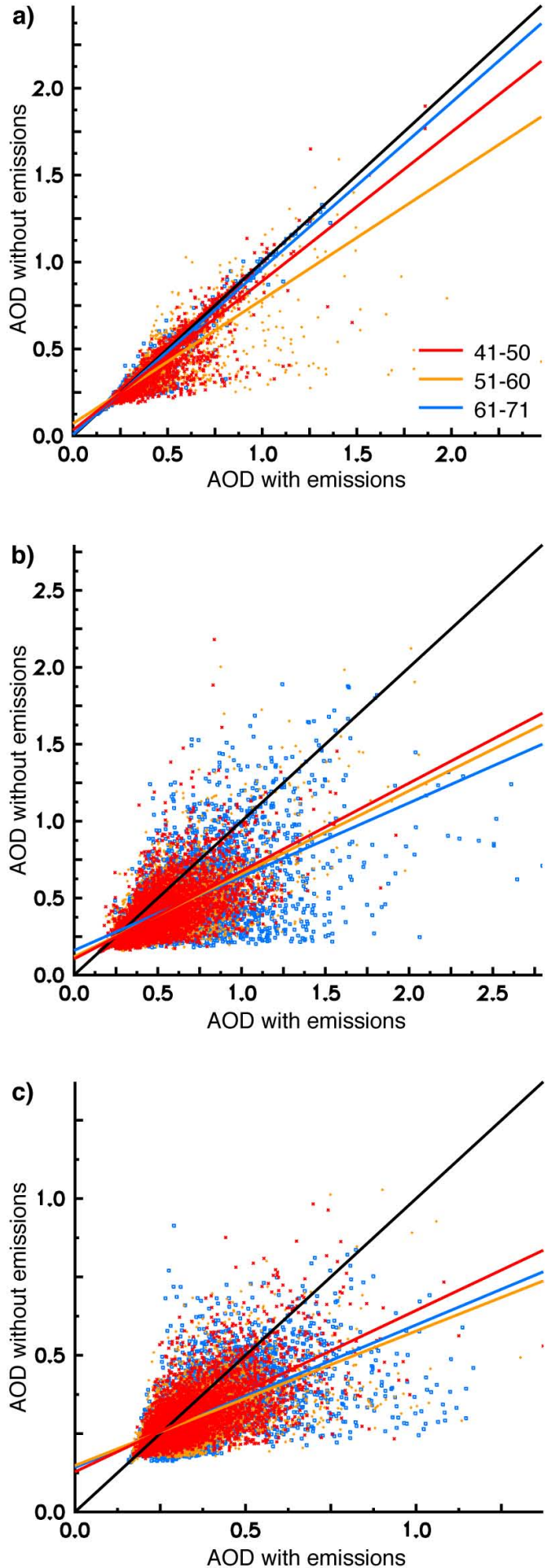

Fig. 10. Comparison of Domain 2 simulated aerosol optical depths for baseline (x-axis) and no point source (y-axis) simulations in non-cloudy cells for 9 August (top), 10 August (middle) and 11 August (bottom). Color coding represents grid cell groupings used as a surrogate for distance from major point sources; see text for further information. move through the modeling domain. Additional studies that examine the impact of aerosols on cloud properties using other microphysics and convective parameterizations are also needed. The large spatial variations in the effects of aerosols on meteorological quantities indicate that statistically verifying trends associated with aerosols will be difficult, given available operational measurements.

Comparison of the baseline and NPS simulations clearly indicates that the addition of the new modules to WRF-Chem has produced changes among the interactions of aerosols, clouds, precipitation, and meteorology. Eliminating one source of aerosol precursors, such as elevated point source emissions, creates complex changes in atmospheric feedbacks and can cause large localized and sporadic differences in a variety of model parameters. Emission control scenarios that reduce, but not eliminate, point source emissions are likely to cause smaller changes than noted in this study.

\section{Summary}

The local and regional influence of elevated point sources on aerosol forcing and cloud-aerosol interactions, including cloud optical properties and precipitation amounts, was investigated using the WRF-Chem community model. New modules were added and existing modules modified to tightly couple aerosols with the cloud physics portion of the model, allowing simulation of the indirect effects of aerosols. The additions included a prognostic treatment of cloud droplet number and modules to handle the activation of aerosol particles that act as CCN to form cloud droplets, to simulate aqueous-phase chemistry, and to tie a two-moment treatment of cloud water (cloud water mass and cloud droplet number) to precipitation and to an existing WRF-Chem radiation scheme. The changes allow the indirect effects of aerosols on clouds and incoming solar radiation to be simulated via fully interactive feedbacks, with aerosols affecting cloud droplet number and cloud radiative properties, and clouds altering aerosol size and composition via aqueous processes, wet scavenging, and gas-phase-related photolytic processes. The importance of using appropriate advection routines, such as the positive definite scheme of Skamarock (2006), when simulating point sources also was demonstrated. Both cloud and aerosol routines in WRF-Chem require zero or positive values and do not allow non-physical negative values. If these negative values are not adequately handled, errors in the form of added mass will result.

Two simulations were conducted to show the impact of elevated point source emissions on the meteorological and aerosol characteristics for western Pennsylvania and downwind regions of eastern North America. The baseline simulation included emissions from the US EPA NEI99 inventory, modified as recommended by Frost et al. (2006) and with time-specific CEM data substituted for the largest $\mathrm{SO}_{2}$ point sources. Comparisons of baseline simulation results 

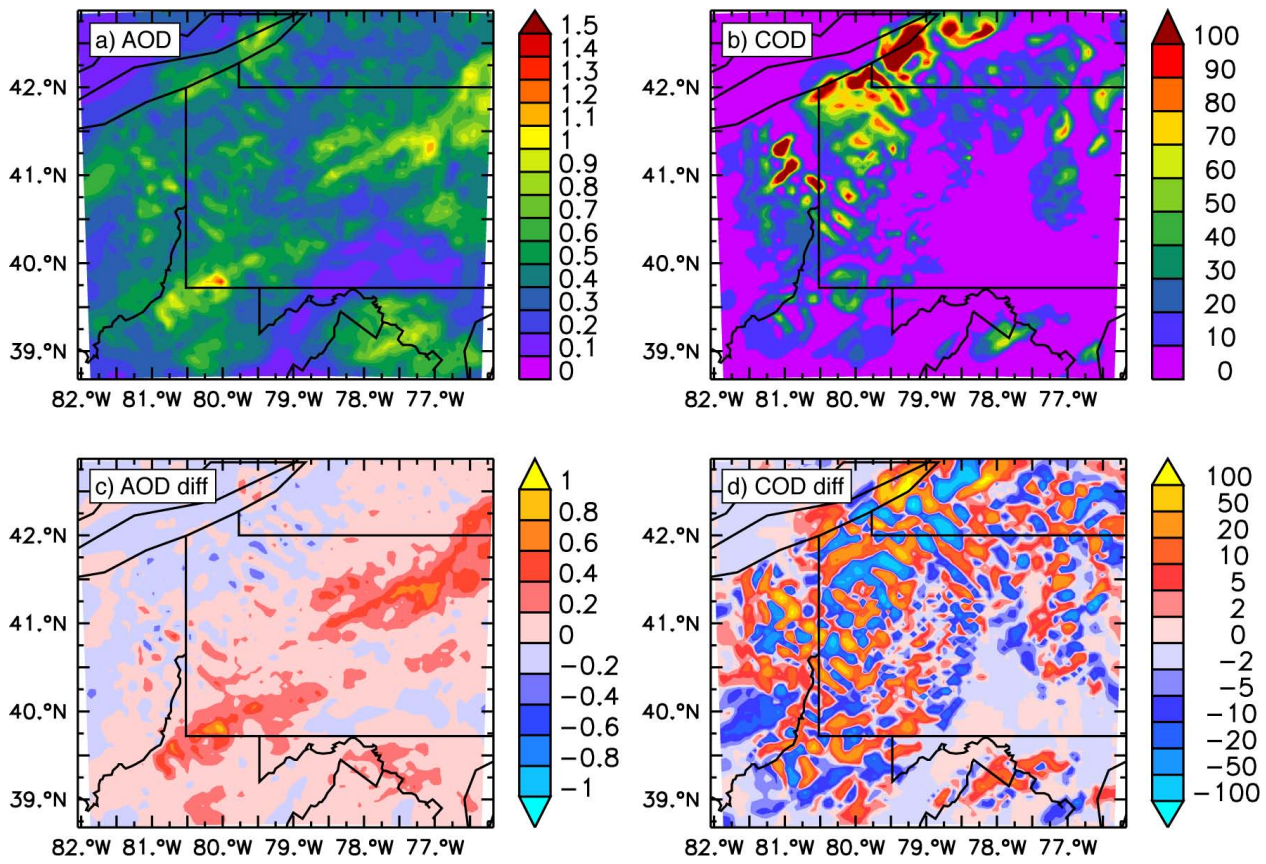

Fig. 11. Simulated Domain 2 baseline (a) aerosol optical depths and (b) cloud optical depths for 10 August 22:00 UTC. AOD (c) and COD (d) differences between baseline and no point source simulations (calculated as [baseline value - no point source value]) are also shown.

with available measurements showed that the model qualitatively captured most of the observed variations in meteorological and chemical parameters. When compared with MFRSR data collected at a ground supersite located near domain center for the period 9 August 06:00 UTC through 11 August 21:00 UTC 2004, the model captured the general temporal cycle of AODs and appeared to produce clouds of comparable thickness to observations at approximately the proper times. The model also showed some skill in capturing the general temporal trend of averaged $\mathrm{PM}_{2.5}$ levels observed at US EPA AQS rural and suburban ground stations, but tended to over-predict the actual $\mathrm{PM}_{2.5}$ mass concentrations. Comparisons of model output with measurements aloft showed that the model also tended to overpredict $\mathrm{SO}_{2}$ mixing ratios, although it performed reasonably well in predicting ozone mixing ratios (generally within 5 to $10 \mathrm{ppb}$ of observations) and aerosol ammonium (generally within $1.5 \mu \mathrm{g} \mathrm{m}^{-3}$ ). The model also simulated the observed range of $\mathrm{SO}_{2}$ to aerosol $\mathrm{SO}_{4}$ ratios quite well, suggesting that the major atmospheric oxidation processes leading to aerosol sulfate formation are captured correctly in the model. However, under such conditions overpredicting $\mathrm{SO}_{2}$ mixing levels will lead to over-predictions of aerosol sulfate, and thus contribute to the model's over-prediction of $\mathrm{PM}_{2.5}$ mass. These over-predictions are likely due to over-estimates in the emissions inventories for $\mathrm{SO}_{2}$ (and probably primary particulates), even with the use of US EPA CEMS modified emissions data. Uncertainties in lateral boundary conditions and deposition treatments may have also contributed to the over-prediction of particulate mass. Measurements of aerosol size distributions were limited, but simulated distributions appeared consistent with observations.

The radiative effects of elevated point source emissions were investigated by comparing the baseline simulation with a sensitivity simulation in which all emissions at model levels above the surface layer were set to zero. Instantaneous, site-specific differences for aerosol and cloud related properties between the two simulations could be quite large. For example, instantaneous differences of over 100 in COD were observed, as removing elevated emission sources influenced when and where clouds formed during the three-day analysis period. The number of model cells exhibiting "thin" clouds (arbitrarily defined as $0<\mathrm{COD} \leq 1$ ) was approximately $4 \%$ higher in the baseline simulation relative to the sensitivity simulation; however, more "non-thin" clouds (COD $>1)$ formed in the sensitivity simulation. When averaged spatially over the finest resolution model domain and temporally over the entire analysis period, clouds formed in the sensitivity simulation tended to be slightly optically thinner while total rainfall increased by $31 \%(483 \mathrm{~cm}$ total rainfall in the baseline simulation versus $633 \mathrm{~cm}$ in the sensitivity simulation). As expected, domain-averaged AODs dropped when elevated emissions were eliminated, from 0.46 in the baseline simulation to 0.38 in the sensitivity simulation. The overall net effect of additional aerosols attributable to elevated point source emissions of primary particulates and aerosol precursors was a domain-averaged reduction of $5 \mathrm{~W} \mathrm{~m}^{-2}$ in mean daytime downwelling shortwave radiation. 
Computational constraints limited the length of the comparative simulations to roughly a 3-day period. Because of this, the results should be viewed as demonstrative of the potential impact of elevated emission point sources on AOD, COD, and rainfall, with more extended simulation periods necessary to determine if the noted changes are typical and will persist.

Acknowledgements. We thank Dr. Stuart McKeen of the NOAA/ESRL for providing the US EPA hourly $\mathrm{PM}_{2.5}$ data, Rahul Zaveri for providing the MOSAIC aerosol model, and the numerous field staff involved with the US DOE portion of the ICARTT/NEAQS 2004 experiment, including Rich Coulter of Argonne National Laboratory, Stephen Springston, Yin-Nan Lee, and Peter Daum of Brookhaven National Laboratory and Carl Berkowitz, Chris Doran, Bob Hannigan, John Hubbe, Nels Laulainen, and Xiao-Ying Yu of Pacific Northwest National Laboratory. We especially thank Mikhail Ovtchinnikov for useful discussions and comments on the manuscript. This research was supported by the US DOE Atmospheric Sciences program of the Office of Biological and Environmental Research under contract DE-AC06-76RLO 1830 at PNNL. PNNL is operated for the US DOE by Battelle Memorial Institute.

Edited by: Y. Balkanski

\section{References}

Abdul-Razzak, H., and Ghan, S. J.: A Parameterization of Aerosol Activation. 3. Sectional Representation, J. Geophys. Res., 107(D3), 4026, doi:10.1029/2001JD000483, 2002.

Akimoto, H.: Global Air Quality and Pollution, Science, 302, 1716-1719, 2003.

Albrecht, B. A.: Aerosols, Cloud Microphysics, and Fractional Cloudiness, Science, 245, 1227-1230, 1989.

Anttila, T., Vehkamaki, H., Napari, I., and Kumala, M.: Effect of Ammonium Bisulfate Formation on Atmospheric Water-Sulfuric Acid-Ammonia Nucleation, Boreal Environ. Res., 10, 511-523, 2005.

Barnard, J. C., Long, C. N., Kassianov, E. I., McFarlane, S. A., Comstock, J. M., Freer, M., and McFarquhar, G. M.: Development and Evaluation of a Simple Algorithm to Find Cloud Optical Depth with Emphasis on Thin Ice Clouds, Open Atmos. Sci. J., 2, 45-55, doi:10.2174/1874282300802010046, 2008.

Barnard, J. C., Chapman, E. G., Fast, J. D., Schemlzer, J. R., Slusser, J. R., and Shetter, R. E.: An Evaluation of the FAST-J Photolysis Algorithm for Predicting Nitrogen Dioxide Photolysis Rates under Clear and Cloudy Sky Conditions, Atmos. Environ., 38, 3393-3403, 2004a.

Barnard, J. C. and Long, C. N.: A Simple Empirical Equation to Calculate Cloud Optical Thickness Using Shortwave Broadband Measurements, J. Appl. Meteor., 43, 1057-1066, 2004 b.

Binkowski, F. S., and Shankar, U.: The Regional Particulate Matter Model: 1. Model Description and Preliminary Results, J. Geophys. Res., 100, 26191-26209, 1995.

Charlson, R. J., Schwartz, S. E., Hales, J. M., Cess, R. D., Coakley, Jr., J. A., Hansen, J. E., and Hofmann, D. J.: Climate Forcing by Anthropogenic Aerosols, Science, 255, 5043, 423-430, doi:10.1126/science.255.5043.423, 1992.
Chen, S.-H., and Sun, W.-Y.: A One-Dimensional Time Dependent Cloud Model, J. Meteor. Soc. Japan, 80, 99-118, 2002.

Chou, M. D., Suarez, M. J., Ho, C. H., Yan, M. M. H., and Lee, K. T.: Parameterizations for Cloud Overlapping and Shortwave Single-Scattering Properties for Use in General Circulation and Cloud Ensemble Models, J. Clim., 11, 202-214, 1998.

Easter, R. C., Ghan, S. J., Zhang, Y., Saylor, R. D., Chapman, E. G., Laulainen, N. S., Abdul-Razzak, H., Leung, L. R., Bian, X., and Zaveri, R. A.: MIRAGE: Model Description and Evaluation of Aerosols and Trace Gases, J. Geophys. Res.-Atmos., 109, D20210, doi:10.1029/2004JD004571, 2004.

Fahey, K. M., and Pandis, S. N.: Optimizing Model Performance: Variable Size Resolution in Cloud Chemistry Modeling, Atmos. Environ., 35, 4471-4478, 2001.

Fast, J. D., Gustafson, Jr., W. I., Easter, R. C., Zaveri, R. A., Barnard, J. C., Chapman, E. G., Grell, G. A., and Peckham, S. E.: Evolution of Ozone, Particulates and Aerosol Direct Radiative Forcing in the Vicinity of Houston Using a Fully Coupled Meteorology-Chemistry-Aerosol Model, J. Geophys. Res., 111, D21305, doi:10.1029/2005JD006721, 2006.

Fehsenfeld, F. C., Ancellet, G., Bates, T. S., et al.: International Consortium for Atmospheric Research on Transport and Transformation (ICARTT): North America to Europe - Overview of the 2004 Summer Field Study, J. Geophys. Res., 111, D23S01, doi:10.1029/2006JD007829, 2006.

Finlayson-Pitts, B. J. and Pitts Jr., J. N.: Chemistry of the Upper and Lower Atmosphere, Academic Press, San Diego, CA, USA, 294-380, 2000.

Frost, G. J., McKenn, S. A., Trainer, M., Ryerson, T. B., Holloway, J. S., Sueper, D. T., Fortin, T., Parish, D. D., and Fehsenfeld, F. C.: Effects of Changing Power Plant $\mathrm{NO}_{\mathrm{x}}$ Emissions on Ozone in the Eastern United States: Proof of Concept. J. Geophys. ResAtmos., 111, D12306, doi:10.1029/2005JD006354, 2006.

Ghan. S. J., and Schwartz, S. E.: Aerosol Properties and Processes: A Path from Field and Laboratory Measurements to Global Climate Models, B. Am. Meteor. Soc., 88, 1059-1083, 2007.

Ghan, S. J. and Easter, R. C.: Impact of Cloud-Borne Aerosol Representation on Aerosol Direct and Indirect Effects, Atmos. Chem. Phys. 6, 4163-4174, 2006.

Ghan, S. J., Easter, R. C., Chapman, E. G., Abdul-Razzak, H., Zhang, Y., and Leung, L. R., Laulainen, N. S, Saylor, R. D., and Zaveri, R. A.: A Physically Based Estimate of Radiative Forcing by Anthropogenic Sulfate Aerosol, J. Geophys. Res-Atmos., 106, 5279-5293, 2001a.

Ghan, S., Laulainen, N., Easter, R., Wagener, R., Nemesure, S., Chapman, E., Zhang, Y., and Leung, R.: Evaluation of Aerosol Direct Radiative Forcing in MIRAGE, J. Geophys. Res-Atmos., 106, 5295-5316, 2001b.

Ghan, S. J., Easter, R. C., Hudson, J., and Breon, F.-M.: Evaluation of Aerosol Indirect Radiative Forcing in MIRAGE, J. Geophys. Res-Atmos., 106, 5317-5334, 2001c.

Ghan, S. J., Leung, L. R., Easter, R. C. and Abdul-Razzak, H.: Prediction of Droplet Number in a General Circulation Model, J. Geophys. Res., 102, 21 777-21 794, 1997.

Gilliani, N. and Pleim, J. E.: Sub-Grid Features on Athropogenic Emissions of $\mathrm{NO}_{\mathrm{x}}$ and VOC in the Context of Regional Eulerian Models, Atmos. Environ., 30, 2043-2059, 1996.

Grell, G. A., Peckham, S. E., Schmitz, R., McKenn, S. A., Frost, G., Skamarock, W. C., and Eder, B.: Fully Coupled "Online" 
Chemistry within the WRF Model, Atmos. Environ., 39, 69576975, 2005.

Gustafson Jr., W. I., Chapman, E. G., Ghan, S. J., Easter, R. C., Fast, and J. D.: Impact on Modeled Cloud Characteristics Due to Simplified Treatment of Uniform Cloud Condensation $\mathrm{Nu}$ clei During NEAQS 2004, Geophys. Res. Lett., 34, L19809, doi:10.1029/2007GL030021, 2007.

Hansen, J., Sato, M., and Ruedy, R.: Radiative Forcing and Climate Response, J. Geophys. Res., 102, 6831-6864, 1997.

Hobbs, P. V., Garrett, T. J., Ferek, R. J., et al.: Emissions from Ships with Respect to Their Effects on Clouds, J. Atmos. Sci., 57, 2570-2590, 2000.

Haywood, J., and Boucher, O.: Estimates of the Direct and Indirect Radiative Forcing Due to Tropospheric Aerosols: A Review. Rev. Geophys. 38, 513-543, 2000.

Jacobson, M. Z., Turco, R. P., Jensen, E. J., and Toon, O. B.: Modeling Coagulation Among Particles of Different Composition and Size, Atmos. Environ., 28, 1327-1338, 1994.

Jankov, I., Gallus, W. A., Segal, M., Shaw, B., and Koch, S. E.: The Impact of Different WRF Model Physical Parameterizations and Their Interactions on Warm Season MCS Rainfall, Weather Forecast., 20, 1048-1060, 2005.

Jones, A., Roberts, D. L., and Slingo, A.: A Climate Model Study of Indirect Radiative Forcing by Anthropogenic Sulphate Aerosols, Nature, 370, 450-453, 1994.

Kiehl, J. T. and Briegleb, B. P.: The Relative Roles of Sulfate Aerosols and Greenhouse Gases in Climate Forcing, Science, 260, 5106, 311-314, doi:10.1126/scienc.260.5106.311, 1993.

Lin, Y.-L., Farley, R. D., and Orville, H. D.: Bulk Parameterization of the Snow Field in a Cloud Model, J. Climate Appl. Meteor., 22, 1065-1092, 1983.

Liu, Y., Daum, P. H., and McGraw, R. L.: Size Truncation Effect, Threshold Behavior, and a New Type of Autoconversion Parameterization, Geophys. Res. Lett., 32, L11811, doi:10.1029/2005GL022636, 2005.

Liu, Y., Bourgeois, A., Warner, T., Swerdlin, S., and Hacker, J.: Implementation of Observation-Nudging Based on FDDA into WRF for Supporting AFEC Test Operations. 6th WRF Conference, NCAR, Boulder, Colorado, USA, 2006.

McKeen, S., Wilczak, J., Grell, G., et al.: Assessment of an Ensemble of Seven Real-Time Ozone Forecasts Over Eastern North America During the Summer of 2004, J. Geophys. Res., 110, D21307, doi:10.1029/2005JD005858, 2005.

McKeen, S., Chung, S. H., Wilczak, J., et al.: Evaluation of Several $\mathrm{PM}_{2.5}$ Forecast Models Using Data Collected During the ICARTT/NEAQS 2004 Field Study, J. Geophys. Res., 112, D10S20, doi:10.1029/2006JD007608, 2007.

Merikanto, J., Napari, I., Vehkamaki, H., Anttila, T., and Kulmala, M.: New Parameterization of Sulfuric Acid-AmmoniaWater Ternary Nucleation Rates of Tropospheric Conditions, J. Geophys. Res., 112, D15207, doi:10.1019/2006JD007977, 2007.

Mesinger, F., DiMego, G., Kalnay, E., et al.: North American Regional Reanalysis, B. Am. Meteor. Soc., 87, 343-360, 2006.

Michalsky, J. J., Schlemmer, J. A., Berkheiser, W. E., Berndt, J. L., Harrison, L. C., Laulainen, N. S., Larson, N. R., and Barnard, J. C.: Multiyear Measurements of Aerosol Optical Depth in the Atmospheric Radiation Measurement and Quantitative Links Programs. J. Geophys. Res., 106, 12099-12107, 2001.

Min, Q. and Harrison, L. C.: Cloud Properties Derived from Surface
MFRSR Measurements and Comparison with GOES Results at the ARM SGP Site, Geophys. Res. Lett., 23, 1641-1644, 1996.

Napari, I., Noppel, M., Vehkamaki, H. and Kulmala, M.: Parameterization of Ternary Nucleation Rates for $\mathrm{H}_{2} \mathrm{SO}_{4}-\mathrm{NH}_{3}-\mathrm{H}_{2} \mathrm{O}$ Vapors, J. Geophys. Res.-Atmos., 107 , doi:10.1029/2002JD002132, 2002.

Ovtchinnikov, M., and Easter, R. C.: Nonlinear Advection Algorithms Applied to Inter-Related Tracers: Errors and Implications for Modeling Aerosol-Cloud Interactions, Mon. Weather Rev., doi:10.1175/2008MWR2626.1, in press, 2009.

Pincus, R. and Baker, M.: Precipitation, Solar Absorption, and Albedo Susceptibility in Marine Boundary Layer Clouds, Nature, 372, 250-252, 1994.

Qian, Y. and Giorgi, F.: Regional Climatic Effects of Anthropogenic Aerosols? The Case of Southwestern China. Geophys. Res. Lett., 27, 3521-3524, doi:10.1029/2000GL011942, 2000.

Ramanathan, V., Crutzen, P. J., Kiehl, J. T., and Rosenfeld, D.: Aerosols, Climate and the Hydrological Cycle, Science, 294, 2119-2124, 2001.

Rutledge, S. A. and Hobbs, P. V.: The Mesoscale and Microscale Structure and Organization of Clouds and Precipitation in Midlatitude Cyclones. XII: A Diagnostic Modeling Study of Precipitation Development in Narrow Cold-Frontal Rainbands, J. Atmos. Sci., 20, 2949-2972, 1984.

Seinfeld, J. and Pandis, S.: Atmospheric Chemistry and Physics, John Wiley \& Sons, New York, NY, USA, 408-448, 1998.

Skamarock, W. C.: Positive-Definite and Monotonic Limiters for Unrestricted-Time-Step Transport Schemes, Mon. Weather Rev., 134, 2241-2250, 2006.

Skamarock, W. C., Klemp, J. B., Dudhia, J., Gill, D. O., Barker, D. M., Wang, W., and Powers, J. G.: A Description of the Advanced Research WRF Version 2. NCAR Technical Note, NCAR/TN-468+STR, 88 pp, National Center for Atmospheric Research, Boulder, Colorado, USA, 2005, available at: http: //wrf-model.org/wrfadmin/publications.php

Smith, J. N., Dunn, M. J., VanReken, T. M., Iida, K., Stolzenburg, M. R., McMurry, P. H., and Huey, L. G.: Chemical Composition of Atmospheric Nanoparticles Formed from Nucleation in Tecamac, Mexico: Evidence for an Important Role for Organic Species in Nanoparticle Growth, Geophys. Res. Lett., 35, L04808, doi:10.1029/2007GL032523, 2008.

Stern, R., Builtjes, P., Schaap, M., Timeermans, R., Vautard, R., Hodzic, A., Memmesheimer, M., Feldmann, H., Renner, E., Wolke, R., and Kerschbaumer, A.: A Model Inter-Comparison Study Focusing on Episodes with Elevated $\mathrm{PM}_{10}$ Concentrations. Atmos. Environ., 42, 4567-4588, doi:10.1016/j.atmosenv.2008.01.068, 2008.

Tao, W. K., Simpson, J., and McCumber, M.: An Ice-Water Saturation Adjustment. Mon. Weather Rev., 117, 231-235, 1989.

Twomey, S.: Pollution and the Planetary Albedo, Atmos. Environ., 8, 1251-1256, 1974.

Twomey, S.: Aerosols, Clouds and Radiation, Atmos. Environ., 25, 2435-2442, 1991.

US Environmental Protection Agency, $\mathrm{NO}_{\mathrm{x}}$ Budget Program: 19992002 Progress Report, Report No. EPA-430-R-03-900, Washington DC, http://www.epa.gov/airmarkets/progress/docs/otcreport pdf, 2003.

Wesely, M. L.: Parameterization of Surface Resistance to Gaseous Dry Deposition in Regional Numerical Models, Atmos. Environ., 
23, 1293-1304, 1989.

Wexler, A. S., Lurmann, F. W., and Seinfeld, J. H.: Modelling Urban and Regional Aerosols-I. Model Development, Atmos. Environ., 28, 531-546, 1994.

Wild, O., Zhu, X., and Prather, M. J.: Fast-J: Accurate Simulation of In- and Below-Cloud Photolysis in Tropospheric Chemical Models, J. Atmos. Chem., 37, 245-282, 2000.

Yu, H., Kaufmann, Y. J., and Chin, M., et al.: A Review of Measurement-Based Assessments of the Aerosol Direct Radiative Effect and Forcing, Atmos. Chem. Phys., 6, 613-666, 2006, http://www.atmos-chem-phys.net/6/613/2006/.

Yu, S., Mathur, R., Schere, K., Kang, D., Pleim, J., and Otte, T. L.: A Detailed Evaluation of the Eta-CMAQ Forecast Model Performance for $\mathrm{O}_{3}$, Its Related Precursors, and Meteorological Parameters During the 2004 ICARTT Study, J. Geophys. Res., 112, D12S14, doi:10.1029/2006JD007715, 2007.

Zaveri, R. A. and Peters, L. K.: A New Lumped Structure Photochemical Mechanism for Large-Scale Applications, J. Geophys. Res., 104, 30387-30415, 1999.
Zaveri, R. A., Easter, R. C., and Wexler, A. S.: A new method for multicomponent activity coefficients of electrolytes in aqueous atmospheric particles, J. Geophys. Res., 110, D02201, doi:10.1029/2004JD004681, 2005a.

Zaveri, R. A., Easter, R. C., and Peters, L. K.: A Computationally Efficient Multi-Component Equilibrium Solver for Aerosols (MESA), J. Geophys. Res., 110, D24203, doi:10.1029/2004JD005618, 2005b.

Zaveri, R. A., Easter, R. C., Fast, J. D., and Peters, L. K.: Model for Simulating Aerosol Interactions and Chemistry (MOSAIC), J. Geophys. Res., 113, D13204, doi:10.1029/2007JD008782.

Zhang, Y., Easter, R. C., Ghan, S. J., and Abdul-Razzak, H.: Impact of Aerosol Size Representation on Modeling Aerosol-Cloud Interactions, J. Geophys. Res., 107, 4558, doi:10.1029/2001JD001549, 2002. 